Article

\title{
Antibacterial Activity of Biosynthesized Selenium Nanoparticles Using Extracts of Calendula officinalis against Potentially Clinical Bacterial Strains
}

\author{
José A Hernández-Díaz ${ }^{1,+}+\mathbb{D}$, Jorge JO Garza-García ${ }^{1,+}{ }^{\dagger}$ Janet M León-Morales ${ }^{2}{ }^{\circledR}$, Adalberto Zamudio-Ojeda ${ }^{3}$, \\ Jenny Arratia-Quijada ${ }^{4, *}$, Gilberto Velázquez-Juárez ${ }^{3}$ [D Julio C López-Velázquez ${ }^{1}$ (i) \\ and Soledad García-Morales $2, *$ (D)
}

check for

updates

Citation: Hernández-Díaz, J.A.; Garza-García, J.J.; León-Morales, J.M.; Zamudio-Ojeda, A.; Arratia-Quijada, J.; Velázquez-Juárez, G.; López-Velázquez, J.C.; García-Morales, S. Antibacterial Activity of Biosynthesized Selenium Nanoparticles Using Extracts of Calendula officinalis against Potentially Clinical Bacterial Strains. Molecules 2021, 26, 5929. https://doi.org/ $10.3390 /$ molecules26195929

Academic Editors: Miguel Ángel

Morcillo Alonso and

Jorge Rubio-Retama

Received: 14 September 2021

Accepted: 27 September 2021

Published: 30 September 2021

Publisher's Note: MDPI stays neutral with regard to jurisdictional claims in published maps and institutional affiliations.

Copyright: (c) 2021 by the authors. Licensee MDPI, Basel, Switzerland. This article is an open access article distributed under the terms and conditions of the Creative Commons Attribution (CC BY) license (https:/ / creativecommons.org/licenses/by/ $4.0 /)$.
1 Department of Plant Biotechnology, Centro de Investigación y Asistencia en Tecnología y Diseño del Estado de Jalisco, Camino Arenero 1227, 45019 Zapopan, Mexico; cepe_armando@hotmail.com (J.A.H.-D.); jona_jjo@hotmail.com (J.J.G.-G.); jucelopez_al@ciatej.edu.mx (J.C.L.-V.)

2 Department of Plant Biotechnology, CONACYT-Centro de Investigación y Asistencia en Tecnología y Diseño del Estado de Jalisco, Camino Arenero 1227, 45019 Zapopan, Mexico; jmlm21@outlook.es

3 Centro Universitario de Ciencias Exactas e Ingenierías, Universidad de Guadalajara, Boulevard Gral. Marcelino García Barragán 1421, 44430 Guadalajara, Mexico; nanozam@gmail.com (A.Z.-O.); gilberto.velazquez@academicos.udg.mx (G.V.-J.)

4 Departamento de Ciencias Biomédicas, Centro Universitario de Tonalá, Universidad de Guadalajara, Av. Nuevo Periférico Oriente 555, 45425 Tonalá, Mexico

* Correspondence: jenny.arratia@academicos.udg.mx (J.A.-Q.); smorales@ciatej.mx (S.G.-M.)

+ These authors contributed equally to this work.

Abstract: The use of selenium nanoparticles (SeNPs) in the biomedical area has been increasing as an alternative to the growing bacterial resistance to antibiotics. In this research, SeNPs were synthesized by green synthesis using ascorbic acid (AsAc) as a reducing agent and methanolic extract of Calendula officinalis L. flowers as a stabilizer. Characterization of SeNPs was performed by UV-vis spectrophotometry, infrared spectrophotometry (FTIR), scanning electron microscopy (SEM), energy dispersive X-ray spectroscopy (EDX), and transmission electron microscopy (TEM) techniques. SeNPs of 40-60 nm and spherical morphologies were obtained. The antibacterial activity of marigold extracts and fractions was evaluated by disk diffusion methodology. The evaluation of SeNPs at different incubation times was performed through the colony-forming unit (CFU) count, in both cases against Serratia marcescens, Enterobacter cloacae, and Alcaligenes faecalis bacteria. Partial antibacterial activity was observed with methanolic extracts of marigold leaves and flowers and total inhibition with SeNPs from $2 \mathrm{~h}$ for $S$. marcescens, $1 \mathrm{~h}$ for E. cloacae, and $30 \mathrm{~min}$ for A. faecalis. In addition, SeNPs were found to exhibit antioxidant activity. The results indicate that SeNPs present a potentiated effect of both antimicrobial and antioxidant activity compared to the individual use of marigold extracts or sodium selenite $\left(\mathrm{Na}_{2} \mathrm{SeO}_{3}\right)$. Their application emerges as an alternative for the control of clinical pathogens.

Keywords: selenium nanoparticles; antibacterial activity; green synthesis; biomedical applications

\section{Introduction}

Nanotechnology is an emerging area of science that deals with the study and manipulation of matter at the molecular and atomic levels [1]. With the emergence of nanotechnology, a new industrial revolution was generated that impacted the world, especially in the biomedical area, where the physicochemical and biological properties of nanoparticles (NPs) have been widely used and exploited [2]. It gave rise to nanomedicine, considered a new discipline of medicine, whose main areas of application include diagnostics, imaging, and smart drug delivery systems to increase therapeutic efficiency by selective delivery to specific targets [3], as well as the generation of diverse nanomaterials against pathogenic microorganisms such as fungi and bacteria [4]. 
In general, one of the fundamental characteristics of NPs is that they have a larger surface area, a property different from those of ionic or metallic elements on a macroscopic scale [5]. Due to this, interest has arisen in using elements such as selenium (Se) to obtain NPs. Se is a fundamental trace element for human health, which has structural and enzymatic functions necessary for the proper functioning of the immune system, counteracting the incidence of viruses such as HIV and maintaining sperm motility [6]. However, it has been reported that inorganic Se presents a high degree of toxicity in the human system when exceeding the recommended dose $(0.070 \mathrm{mg} \mathrm{Se} /$ day for men and $0.060 \mathrm{mg} \mathrm{Se} /$ day for women) [5]. On the contrary, the use of SeNPs reduces the possible damage caused to the organism, representing a new mechanism of transport and nanomedical application [7]. It could be exploited to treat many affections, such as cancer, diabetes, and diseases caused by viruses and bacteria, since it has also been shown to have antioxidant and antimicrobial properties [8].

In this study, methanolic extracts of marigold leaves and flowers and fractions of the flower extracts were obtained and evaluated as antibacterial agents. From these results, the extract that presented the highest antibacterial activity was used to synthesize SeNPs, using AsAc as a reducing agent and the marigold extract as a stabilizer. The evaluation of the reduction process and stability of SeNPs was performed by UV-vis spectroscopy. FTIR determined the functional groups present in the methanolic extract of marigold flowers and SeNPs. SEM and TEM analyzed the size and morphology of SeNPs. The presence of Se in the analyzed NPs was confirmed by EDX spectroscopy. The antibacterial activity of SeNPs was evaluated by counting colony-forming units as a function of different incubation times against three clinically important bacteria, such as S. marcescens, E. cloacae, and A. faecalis. Finally, the antioxidant activity of the methanol extract of flowers and SeNPs was determined.

\section{Results and Discussion}

\subsection{Antibacterial Activity of Plant Extracts}

Two methanolic extracts of leaves/stems and flowers were evaluated for their antibacterial activity against three Gram-negative bacteria (S. marcescens, E. cloacae, and A. faecalis). Three fraction extracts, hexane $(\mathrm{Hx})$, dichloromethane $\left(\mathrm{CH}_{2} \mathrm{CL}_{2}\right)$, and aqueous, from marigold flowers were tested in the same form. Methanolic extracts of marigold leaves/stems (Coht-Met) and flowers (Cof-Met) exhibited comparable antibacterial activity between them at $300 \mathrm{mg} / \mathrm{mL}$, as shown by the growth inhibition zones (Figure 1a). Comparable results were presented by Efstratiou et al. [9], which demonstrated the antibacterial potential of methanolic extracts of marigold flowers at this same concentration against a large number of bacteria, such as Bacillus subtilis, Escherichia coli, and Staphylococcus aureus. The results of the disk diffusion method indicated that both Coht-Met and Cof-Met had a similar antibacterial effect against $S$. marcescens (Figure 1b). For the case of E. cloacae and A. faecalis, no inhibitory activity of either methanolic extracts or fractions was found. It could be because the compounds present in the extracts/fractions were not active against the microorganisms used [9].

Both the extracts and the fractions showed a change in medium coloration because of the pigment's production as carotenoids (astaxanthin, $\beta$-carotene, zeaxanthin, canthaxanthin, lycopene). The carotenoid's precursors are two $5 \mathrm{C}$ subunits: (a) isopentenyl diphosphate (IPP) and (b) dimethylallyl diphosphate (DMAPP) (isomeric form) through themethylerythritol 4-phosphate (MEP) pathway, as part of the microorganism secondary metabolism. In the specific case of $A$. faecalis, the pigmentation produced by this bacterium can protect against oxidative stressand reinforce bacterial membranes [10]. Based on the results obtained from the evaluation of the antibacterial activity of both the extracts and their fractions, the Cof-Met extract was used to synthesize SeNPs. 


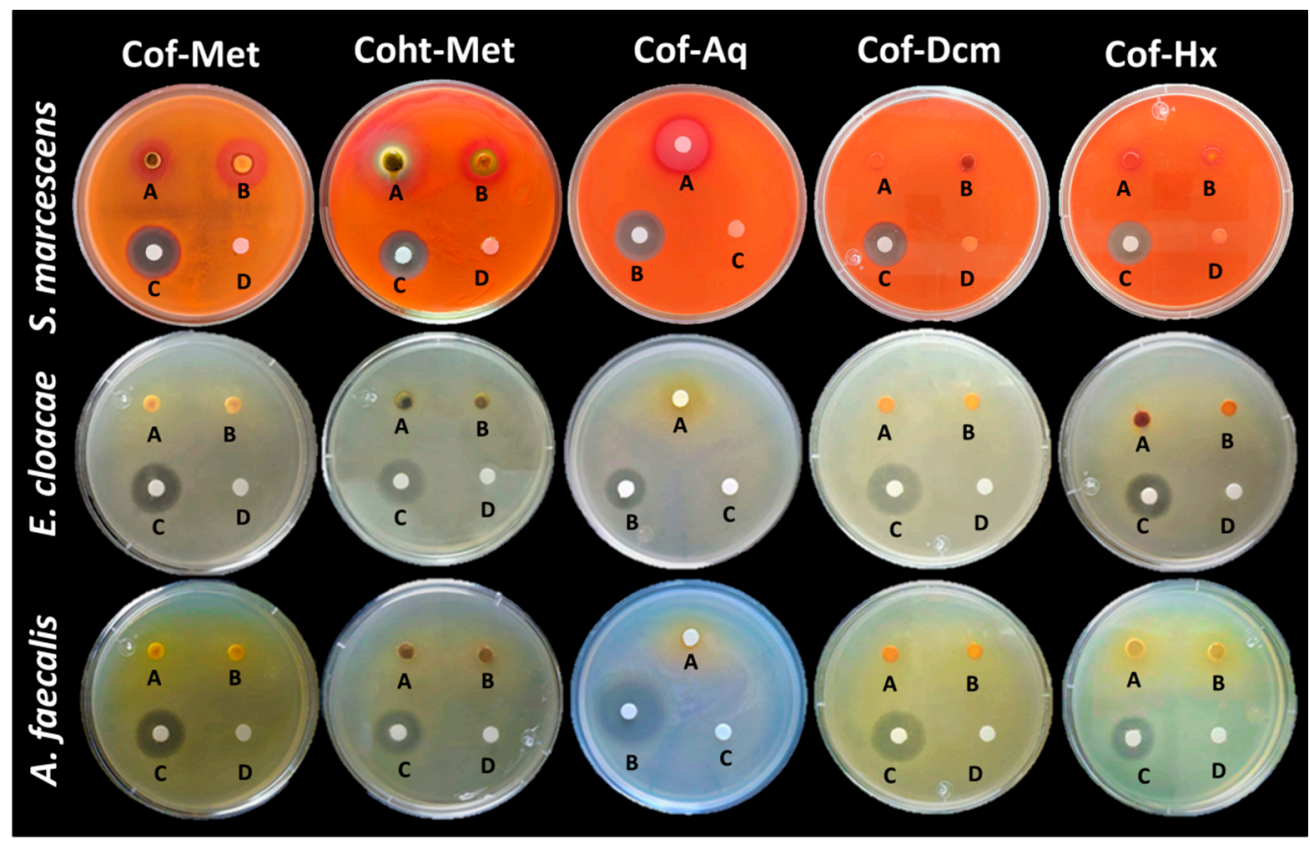

(a)

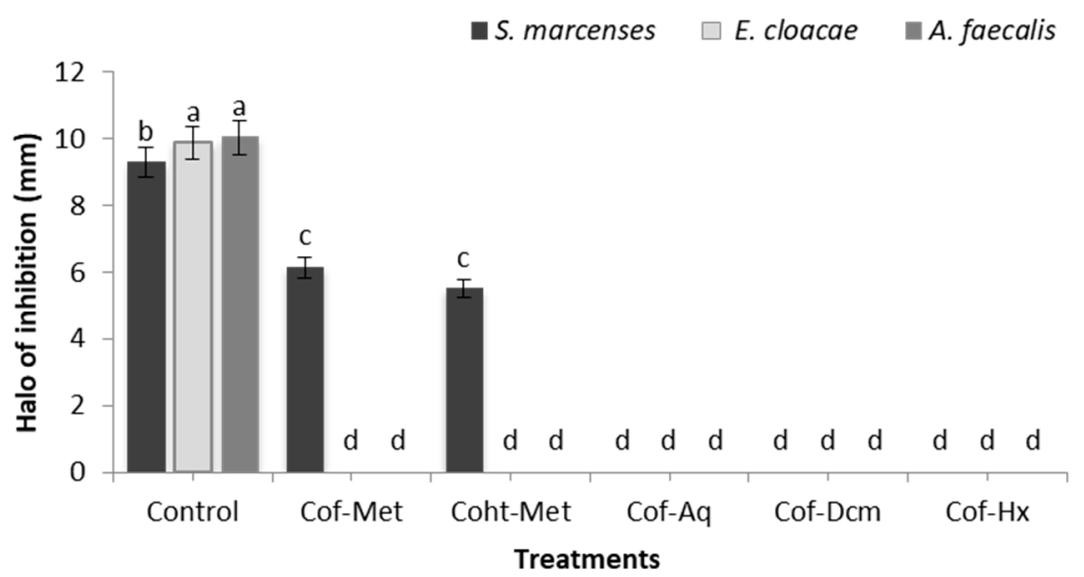

(b)

Figure 1. Antibacterial activity of methanol extracts (leaves/stems and flowers) and fractions (hexane, dichloromethane, and aqueous) of marigold flowers. (a) Inhibition halos with the different extracts and fractions of marigold on $S$. marcenses, E. cloacae, and A. faecalis, Cof-Met $(\mathrm{A}=300 \mathrm{mg} / \mathrm{mL}$, $\mathrm{B}=200 \mathrm{mg} / \mathrm{mL}, \mathrm{C}=$ Control $(S$. marcenses and E. cloacae, gentamicin $(\mathrm{Ge}) 1 \mathrm{mg} / \mathrm{mL}, A$. faecalis, ciprofloxacin (CIP) $1 \mathrm{mg} / \mathrm{mL}), \mathrm{D}=\mathrm{MeOH})$, Coht-Met $(\mathrm{A}=300 \mathrm{mg} / \mathrm{mL}, \mathrm{B}=200 \mathrm{mg} / \mathrm{mL}, \mathrm{C}=\mathrm{Control}$, $\mathrm{D}=\mathrm{MeOH})$, Cof-Aq $\left(\mathrm{A}=300 \mathrm{mg} / \mathrm{mL}, \mathrm{B}=\right.$ Control, $\left.\mathrm{C}=\mathrm{H}_{2} \mathrm{O}\right)$, Cof-Dcm $(\mathrm{A}=300 \mathrm{mg} / \mathrm{mL}$, $\mathrm{B}=200 \mathrm{mg} / \mathrm{mL}, \mathrm{C}=$ Control, $\mathrm{D}=\mathrm{AcEt})$, Cof-Hx $(\mathrm{A}=300 \mathrm{mg} / \mathrm{mL}, \mathrm{B}=200 \mathrm{mg} / \mathrm{mL}, \mathrm{C}=\mathrm{Con}-$ trol, $\mathrm{D}=\mathrm{AcEt})$. (b) Comparison of means of inhibition halos. Mean values $\pm \mathrm{SE}$. Different letters denote statistically significant differences according to Duncan's test $(\alpha=0.05), p<0.0001$. Cof-Met: crude methanolic extract of flowers, Coht-Met: crude methanolic extract of leaves and stems, Cof-Aq: aqueous fraction of flowers, Cof-Dcm: dichloromethane fraction of flowers, Cof-Hx: hexane fraction of flowers.

\subsection{Green Synthesis and Characterization of SeNPs}

NPs were synthesized by reducing $\mathrm{Na}_{2} \mathrm{SeO}_{3}$ semi-metallic ions using AsAc, inducing the formation of nucleation centers, leading to the formation of SeNPs. To the reaction, marigold flower extract was added as a stabilizing agent. Similar data have been reported 
showing that marigold extracts serve as a stabilizing agent during the synthesis of NPs [11]. Likewise, the coloration change of the reaction was examined for $0,3,9,15,30 \mathrm{~min}$, and $24 \mathrm{~h}$, observing the shift from faint yellow to brownish red due to the excitation of the surface plasmon resonance, which indicated the formation of SeNPs. During the formation of SeNPs, similar coloration changes have been reported with green synthesis mediated by Trichoderma spp. [12] and AsAc [13].

The SeNPs were characterized by the UV-vis technique. The UV-vis spectrum shows an absorption peak at a wavelength of $265 \mathrm{~nm}$, scanning in the range of 200 to $400 \mathrm{~nm}$ (Figure 2a). It agrees with Vahdati and Moghadam [14], who report an absorption peak at this wavelength using AsAc for the synthesis of SeNPs. On the other hand, the stability of the SeNPs was verified by measuring the absorbance at different times, finding that the SeNPs stabilized with the marigold extract were stable from $30 \mathrm{~min}$ to $120 \mathrm{~h}$ after synthesis, suggesting the stabilizing capacity of the extract due to the presence of functional groups such as carboxylic acids and amino groups on the surface of the SeNPs, preventing their agglomeration (Figure 2b) [11]. On the other hand, studies by Fierascu et al. [15] revealed that bioactive compounds such as carotenoids and chlorophylls in the plant extract of marigold flowers are responsible for the stability of the NPs.

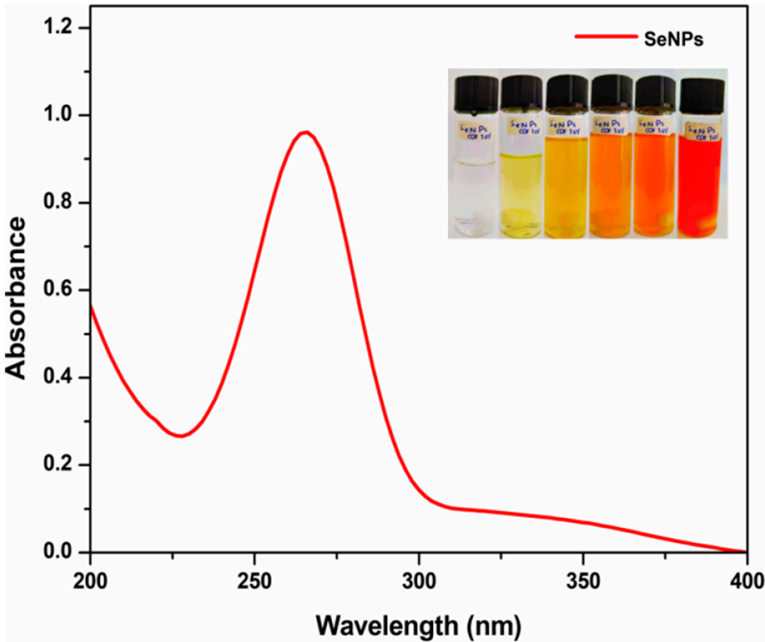

(a)

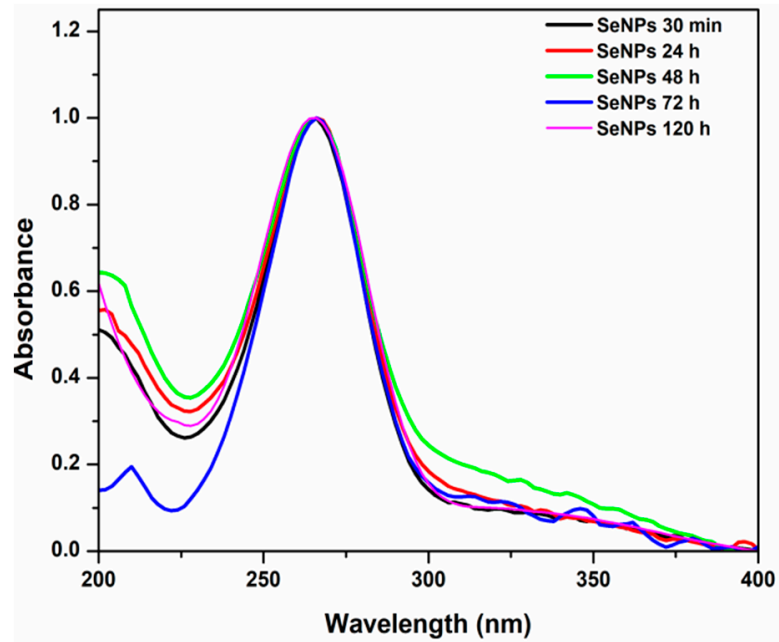

(b)

Figure 2. UV-vis spectra of SeNPs. (a) Characteristic absorption peak andcoloration change from yellow to red during the synthesis of SeNPs mediated by AsAc and methanolic extract (Cof-Met) at 0, 3, 9, 15, 30 min, and $24 \mathrm{~h}$ after the reduction onset. (b) Absorption spectra of SeNPs measured at different times showing the stability of SeNPs.

Regarding the morphology and size of the synthesized SeNPs, the SEM technique was performed at $20 \mathrm{kV}$ and $34 \mathrm{kx}$, using backscattered electrons (Figure 3a), and it was observed that the biosynthesized SeNPs presented a monodisperse spherical morphology with an approximate size of $100 \mathrm{~nm}$. This size obtained by SEM sometimes shows clusters rather than individual SeNPs, making it impractical to identify the boundary between individual NPs. Similar sizes and morphologies of SeNPs have been reported using Pelargonium zonale extract [16]. In this regard, Filipovic et al. [17] demonstrated that the shape and size of NPs are decisive parameters that determine the interaction between NPs and the biological systems in which they are used. In turn, EDX analysis confirmed the presence of elemental Se in the analyzed SeNPs sample (Figure 3b). Characteristic absorption peaks of Se were found at $1.37 \mathrm{keV}$ (SeL $\alpha$ peak) and $11.22 \mathrm{keV}$ (SeK $\alpha$ peak), which is in agreement with the information obtained by Dhanjal and Cameotra, who indicated intense spectral peaks for $\mathrm{SeK} \alpha$ at $11.22 \mathrm{KeV}[18]$. 


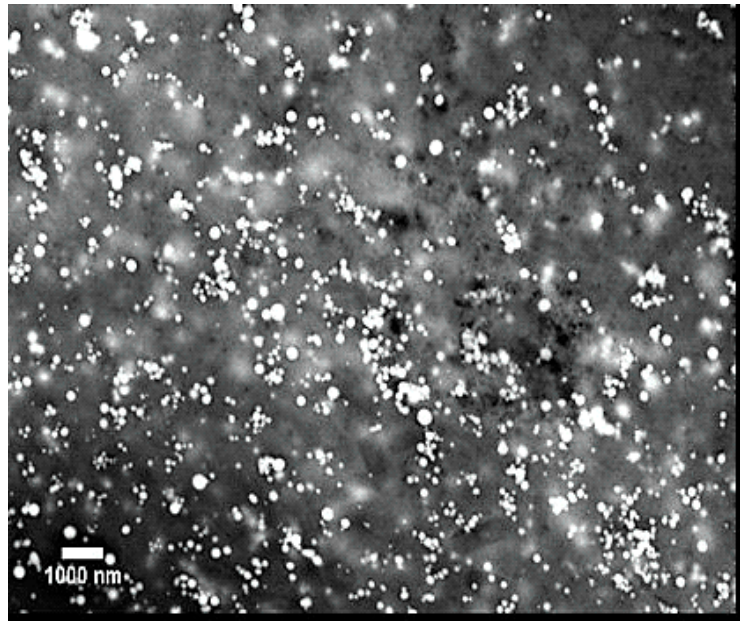

(a)

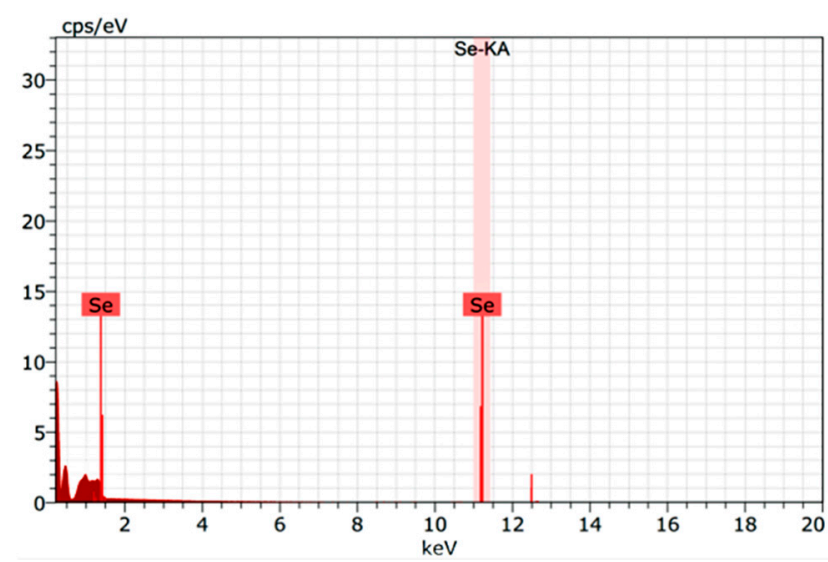

(b)

Figure 3. Characterization of SeNPs. (a) Micrograph of SeNPs at $34 \mathrm{kx}$ by SEM microscopy. (b) EDX spectra showing the presence of Se.

The TEM technique was used to corroborate the shape and size of the synthesized SeNPs. TEM images were obtained at $80 \mathrm{kV}$ and $120 \mathrm{kx}$ magnification. In the micrographs of SeNPs, obtained by AsAc-mediated green synthesis and Cof-Met extract, a spherical morphology and an average frequency size distribution of 40 to $60 \mathrm{~nm}$ in diameter were observed (Figure $4 \mathrm{a}, \mathrm{b}$ ). It has been reported that changes in the morphology and size of NPs may be due to different nucleation and growth mechanisms related to factors such as temperature and reaction time [19]. For example, there are reports that the average size of $\mathrm{Co}-\mathrm{Fe}_{2} \mathrm{O}_{4} \mathrm{NPs}$ increased with exposure to a reaction temperature above $40^{\circ} \mathrm{C}$, increasing from $9 \mathrm{~nm}$ at this temperature to $47 \mathrm{~nm}$ at $100{ }^{\circ} \mathrm{C}$ [20]. This work found that a maximum temperature of $40^{\circ} \mathrm{C}$ for $30 \mathrm{~min}$ resulted in the optimal conditions for obtaining SeNPs with a size below $100 \mathrm{~nm}$.

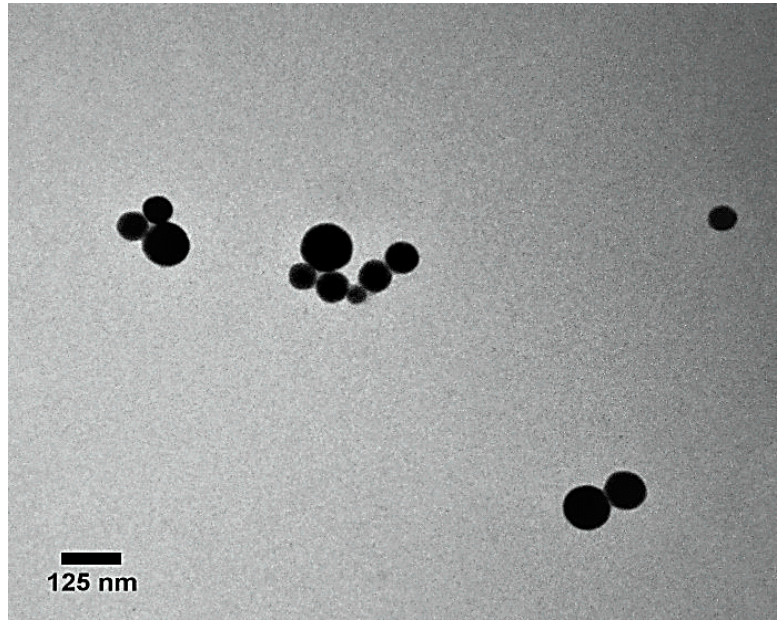

(a)

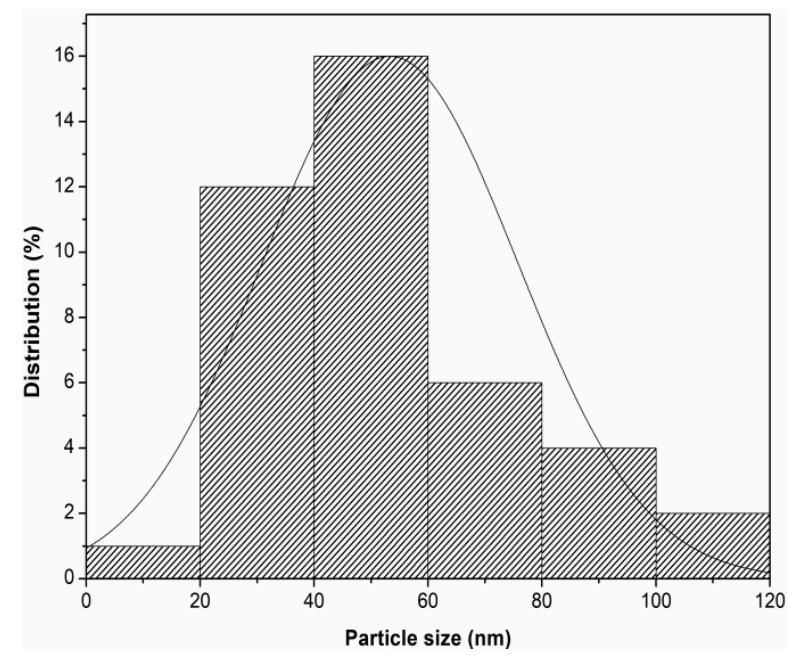

(b)

Figure 4. Characterization of SeNPs by TEM microscopy. (a) Micrograph of SeNPs taken at 120 kx. (b) Size distributionplot of SeNPs.

The results obtained from TEM (Figure 4a) agree with the morphology of the SeNPs found with the SEM technique (Figure 3a). However, SeNPs size was larger by SEM because the energy used in this technique is lower than that required by TEM, which decreases the resolution of the micrographs. 
The infrared spectrum of the Cof-Met extract and SeNPs was measured in the wavelength range of $4000-500 \mathrm{~cm}^{-1}$ (Figure 5). The peaks were found to represent the Cof-Met extract's functional groups, the AsAc, and the interaction with Se. It suggests the ability of marigold extracts to adhere to the surface of NPs as a form of stabilization, as proposed by Olfati et al. [11], who used aqueous extracts of this same plant as a stabilizing agent for NPs. According to the results of the FTIR spectra, it was possible to identify some absorption bands at $3305 \mathrm{~cm}^{-1}$ representing the stretching of the hydroxyl groups $(-\mathrm{OH})$ of alcohols and phenols present in the methanolic extract of flowers. In contrast, a shift of this band to $3277 \mathrm{~cm}^{-1}$ was observed in the SeNPs. This same behavior was presented during the biosynthesis of SeNPs mediated by the aqueous extract of Emblica officinalis fruit, where a band shift from 3382 to $3348 \mathrm{~cm}^{-1}$ was reported, indicating the interaction of Se with the -OH group present in alcohols and phenols of the extracts through hydrogen bonds [21,22]. Similarly, bands at 2924 and $2852 \mathrm{~cm}^{-1}$ were observed, which correspond to functional groups such as carboxylic acid and C-H of alkane groups, possible biomolecules responsible for stabilizing SeNPs [11,23].

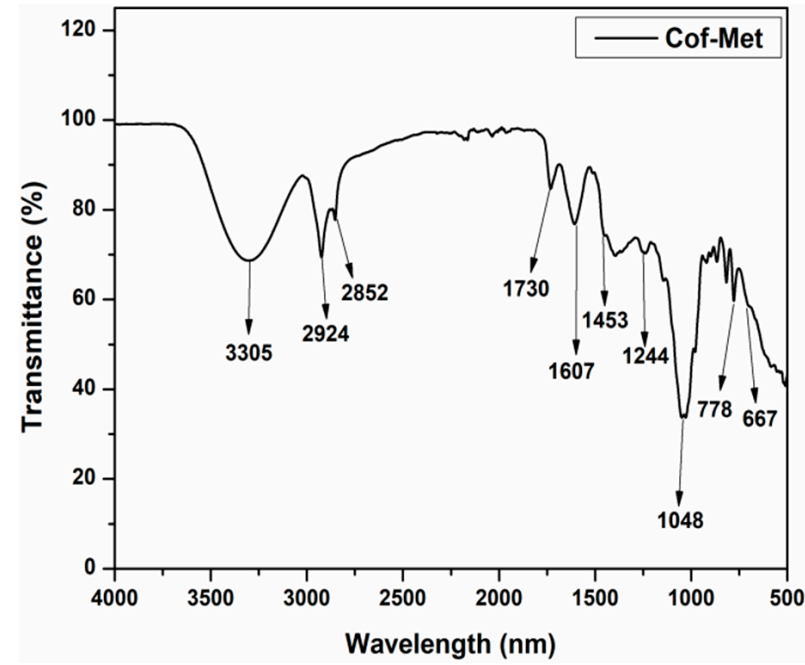

(a)

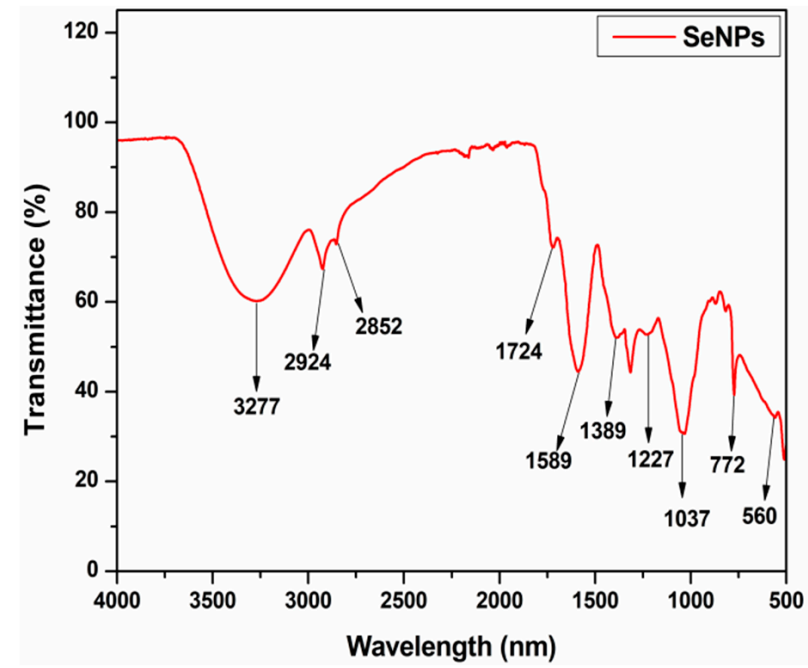

(b)

Figure 5. Fourier transform infrared spectroscopy (FTIR) analysis. (a)FTIR spectra of Cof-Met extract used for the biosynthesis of SeNPs. (b) FTIR spectra of SeNPs.

In turn, the spectrum of the Cof-Met extract (Figure 5a) indicated the presence of bands at 1730 and $1607 \mathrm{~cm}^{-1}$ attributed to stretching and vibrational bending of the carbonyl $(\mathrm{C}=\mathrm{O})$ region and vibrations of soluble protein amides, while for the SeNPs, these bands were shifted to 1724 and $1589 \mathrm{~cm}^{-1}$, respectively. According to Rajathi et al. [24], this behavior could indicate a possible interaction of these compounds with Se. Likewise, the Cof-Met extract presented bands at $1453 \mathrm{~cm}^{-1}$, corresponding to the C-C, C-O, and C-N stretching of organic compounds, and $1048 \mathrm{~cm}^{-1}$ attributable to the $\mathrm{C}-\mathrm{OH}$ stretching of alcohols [25]. At the same time, it has been reported that bands between 1038 and $1602 \mathrm{~cm}^{-1}$ indicate the presence of carbohydrates and proteins [26]. For SeNPs (Figure 5b), the latter band shifted to $1037 \mathrm{~cm}^{-1}$, representing the characteristic vibration of Se-O stretching, achieving the formation of SeNPs in the reducing medium with AsAc, as reported by Kannan et al. [27]. On the other hand, in SeNPs, the band at $560 \mathrm{~cm}^{-1}$ corresponds to the out-of-plane bending vibrations of the aromatic $\mathrm{C}-\mathrm{H}$ groups [28], which, according to Stella et al. [29], originate from the stretching vibrations of the metal-oxygen bond. Likewise, the band at $772 \mathrm{~cm}^{-1}$ was found in SeNPs, as indicated by Jahdaly et al. [30], andsuggests the binding of SeNPs to the -OH groups present in AsAc, giving rise to Se-O coordination bonds between Se and AsAc. The Se-OH interaction nature could be due to the binding of 
the SeNPs to the $\mathrm{C}=\mathrm{O}$ groups of the AsAc oxidation products, forming a layer around the SeNPs to avoid their agglomeration [13].

\subsection{Antibacterial Activity of SeNPS}

Bacterial resistance to antibiotics is one of the significant problems facing medicine. Currently, infection-related problems persist despite the intense efforts made by the scientific community. Given this, many researchers have focused their study on the development of nanostructured inorganic compounds with antimicrobial activity, such as metals, semimetals, metal oxides, non-metal oxides, and others [31]. Among these compounds, the use of SeNPs represents an alternative to conventional products as they are classified as agents with significant antimicrobial activity, especially when dealing with chronic and nosocomial infections caused by bacteria [17].

The antibacterial activity of SeNPs against three Gram-negative bacteria was evaluated by measuring the growth of bacterial colonies at different incubation times and treatments.

S. marcescens was selected because it was initially considered a non-pathogenic bacterium due to its low virulence in healthy populations. However, in the last 30 years, this bacterium has emerged as a nosocomial pathogen causing wound and eye infections, urinary and respiratory tract infections, and causing endocarditis, osteomyelitis, septicemia, and meningitis [32,33]. In several clinical cases of peritoneal dialysis patients, it is considered one of the Gram-negative bacteria with one of the worst diagnoses, causing in some cases the loss of the catheter, the failure of the technique, and the death of the patient [34]. In addition, analyses of S. marcescens have shown an increase in antibiotic resistance. Thus, it is often described as a difficult-to-treat bacterium with a high antibiotic resistance profile [32].

The application of SeNPs against $S$. marcescens showed inhibitory results similar to the control (CIP) after $1 \mathrm{~h}$ of incubation. At the same time, it was determined that after $2 \mathrm{~h}$, the treatment with SeNPs completely inhibited the growth of the bacterium (Figure 6). These results are in agreement with those presented by Menon et al. [35], where the use of SeNPs (size $>100 \mathrm{~nm}$ ) showed significant inhibition on the same bacteria after $5 \mathrm{~h}$ of incubation. Based on these results, it can be established that the size of SeNPs plays a relevant role in antibacterial activity, as described by Jeong et al. [36], who indicated that to achieve a more significant antibacterial effect, NPs should be smaller than $100 \mathrm{~nm}$ in size. The higher antibacterial activity found in this work is due, in part, to the fact that SeNPs have a size between 40 and $60 \mathrm{~nm}$ with a larger contact surface area, and could more easily cross the cell wall and bacterial membrane, inducing cell lysis, interfering with ATP synthesis and affecting cell division, leading to bacterial cell death [37].

These results highlight the importance of SeNPs against non-Pseudomonas Gramnegative bacteria [38]. It is mainly due to the significant increase in the risk of hospitalization caused by S. marcescens compared to other bacteria [39]. One of the mechanisms involved in the pathogenicity of this bacterium in humans is the formation of biofilms, polymeric substances that provide protection against antibiotics and host defense mechanisms. In this sense, it has been reported that NPs can penetrate through biofilms' water channels, causing their disruption [40]. Inhibiting or eliminating the formation of biofilms could be an effective way to reduce their pathogenicity, which could counteract nosocomial infections caused by this bacterium. For the specific case of SeNPs, anti-biofilm efficacy against pathogens such as Bacillus cereus, Enterococcus faecalis, S. aureus, and E. coli have been reported in other studies [41]. Therefore, SeNPs could be used as an alternative for eliminating bacterial biofilms while decreasing the possibility of antibiotic resistance developed by bacteria. 


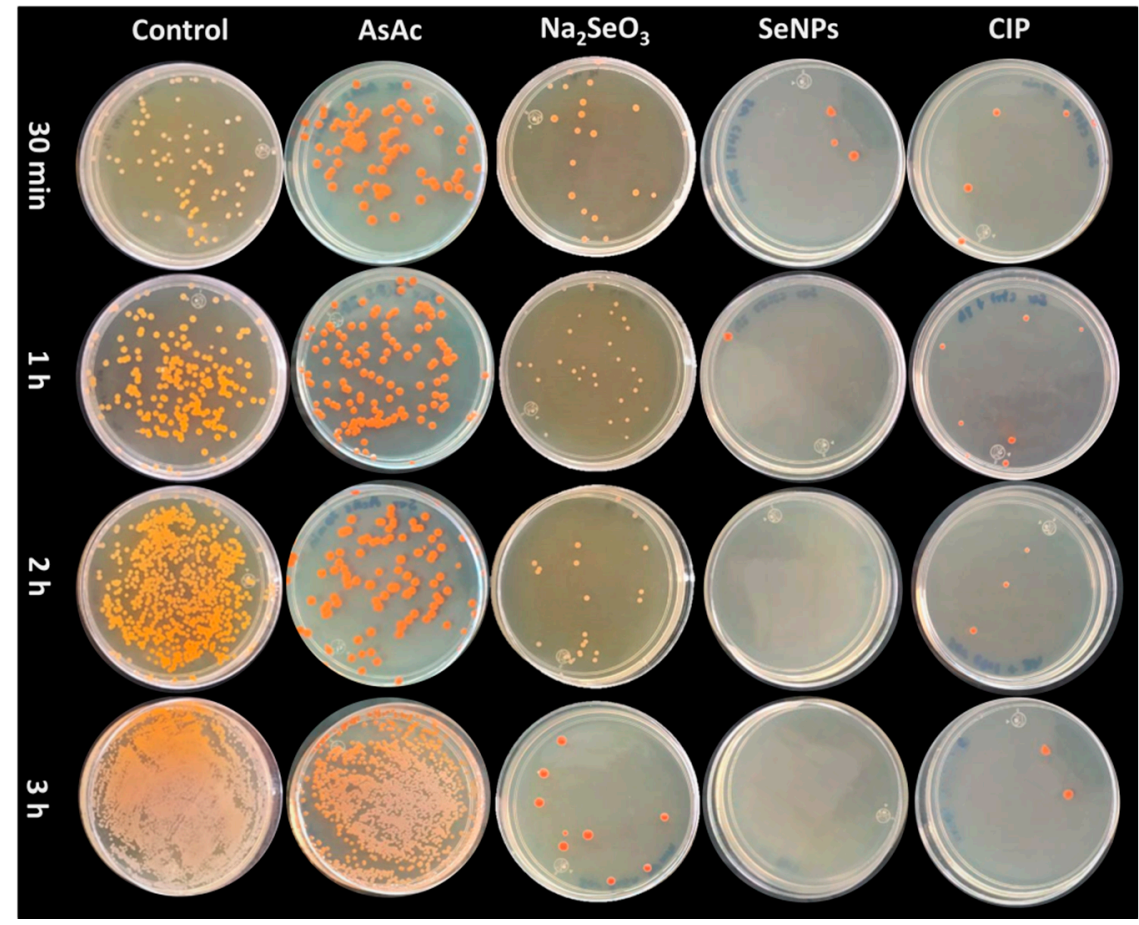

(a)

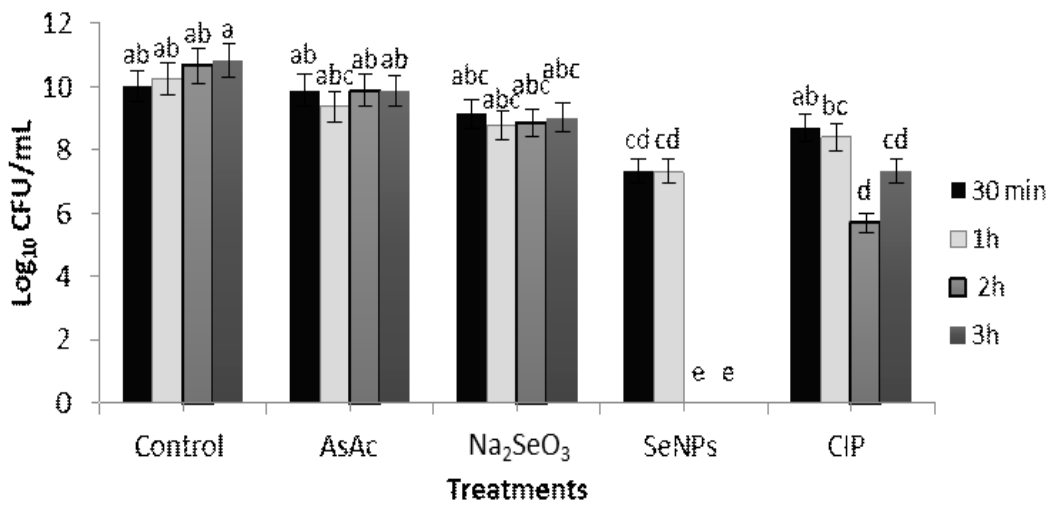

(b)

Figure 6. Antibacterial activity of SeNPs against S. marcescens. (a) Evaluation of antibacterial activity under different treatments and incubation times. (b) Effect of SeNPs on S. marcescens colony formation. Mean values \pm SE. Different letters denote statistically significant differences according to Duncan's test $(\alpha=0.05), p<0.0001$.

The evaluation of the antibacterial activity against E. cloacae was similar to that found in S. marcescens. Partial inhibition of bacterial growth was observed at $30 \mathrm{~min}$ and total inhibition at $1 \mathrm{~h}$ after applying the SeNPs. These results were statistically superior to those obtained by the CIP, which required $3 \mathrm{~h}$ to present a significant inhibition in the formation of bacterial colonies vs. the control (Figure 7a,b). This effect can be attributed to the cell-specific presence of lipopolysaccharide-lipoprotein complexes in the cell wall of Gram-negative bacteria and the presence of transport pumps, which allow bacteria to regulate their internal environment by removing toxic substances such as antimicrobial agents. For the specific case of E. cloacae, the EmmdR pump has been reported, while for $S$. marcescens, the SdeAB pump. In both cases, the presence of these pumps induces resistance in antibiotics such as CIP [42]. These mechanisms prevent antibiotics from reaching the intracellular sites necessary to exert their antibacterial function [43]. It is 
suggested that SeNPs present different mechanisms of action, such as the generation of reactive oxygen species (ROS), disruption of the bacterial cell wall, and inhibition of protein and DNA synthesis [44].

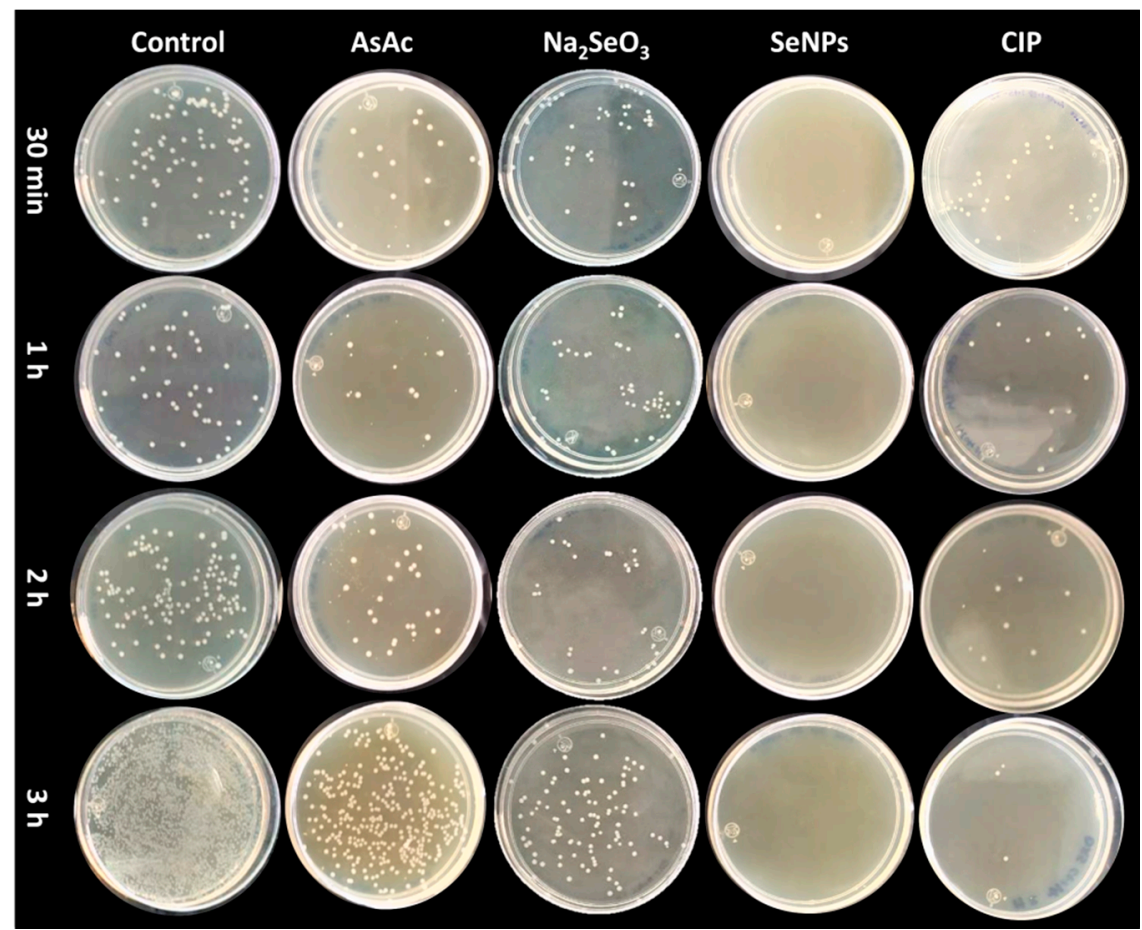

(a)

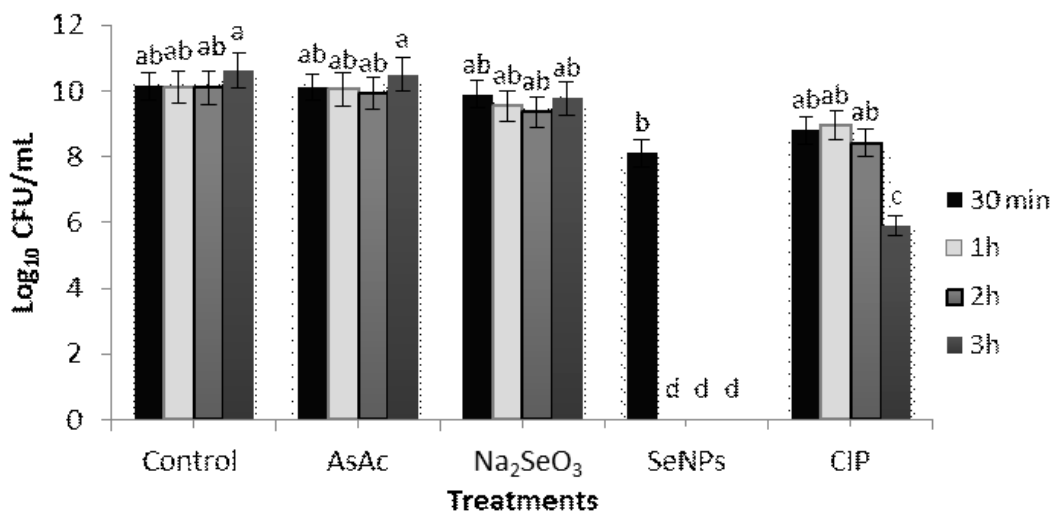

(b)

Figure 7. Antibacterial activity of SeNPs against E. cloacae. (a) Evaluation of antibacterial activity at different treatments and incubation times. (b) Effect of SeNPs on colony formation. Mean values \pm SE. Different letters denote statistically significant differences according to Duncan's test $(\alpha=0.05), p<0.0001$.

In addition, one of the advantages of using NPs as an antibacterial agent is their ability to act through multiple mechanisms, resulting in the inability of pathogens to acquire resistance to them $[17,44]$. In $\mathrm{Na}_{2} \mathrm{SeO}_{3}$, a decrease in CFU was found after 1 and $2 \mathrm{~h}$ of incubation. After $3 \mathrm{~h}$, the trend changed, increasing CFU due to a possible bacterial Se adaptation. So far, it has been reported that bacteria of the genus Pseudomonas [45], E. cloacae [46], and Azoarcus sp. [47] can synthesize SeNPs from $\mathrm{Na}_{2} \mathrm{SeO}_{3}$ as a mechanism to reduce Se toxicity internally. 
A. faecalis is considered as an emerging drug-resistant pathogen, causing opportunistic infections in humans. In most cases, infection generated by A. faecalis is complicated to treat because it is highly resistant to several antibiotics, such as anti-pseudomonal penicillin, cephalosporins, carbapenemics, aminoglycosides, and quinolones [48]. Currently, cases of A. faecalis infection have been identified, including cystitis, skin and soft tissue infection, pneumonia, bacteremia, meningitis, endocarditis, eye infection, peritonitis, and infectious diarrhea [49].

In this research, it was possible to observe an inhibition of total growth from the first incubation time (30 $\mathrm{min}$ ) using SeNPs (Figure $8 \mathrm{a}, \mathrm{b}$ ). It could be due to the content of bioactive compounds in the Cof-Met extracts present on the surface of the SeNPs, capable of damaging the signaling receptors necessary to carry out quorum sensing (QS) [50], a chemical process of cell-to-cell communication used by bacteria such as $A$. faecalis to regulate their virulence and the formation of biofilms [51,52]. This QS inhibition has been reported using SeNPs biosynthesized with AsAc, with the average size of $85 \mathrm{~nm}$, where the inhibition of the biosynthesis of crucial QS compounds such as violacein $(80 \%)$ was demonstrated, suggesting the disruption of the QS signal [53]. On the other hand, CIP showed significant results after $1 \mathrm{~h}$ vs. the control.

Likewise, the results obtained with $\mathrm{Na}_{2} \mathrm{SeO}_{3}$ reflect a similar tendency of adaptation to Se as observed in S. marcescens and E. cloacae. For this case, the ability of A. faecalis to reduce $\mathrm{Na}_{2} \mathrm{SeO}_{3}$ to SeNPs has been reported, establishing as apossible reduction mechanisms the action of cellular reductases and reducing compounds whose production is related to the growth phase of the bacterium [54]. Additionally, the more significant inhibitory activity of AsAc on A. faecalis was observed, which could be related to a decrease in bacterial viability, as obtained by Gnarpe et al. [55], who through treatments with AsAc against $A$. faecalis were able to decrease viable cell counts. This effect could be due, in part, to the fact that bacterial growth is usually slow in acidic media. Therefore, acidifying agents such as AsAc are often used to decrease $\mathrm{pH}$. At the same time, AsAc can interfere with the activity of signaling molecules in the QS such as AI-2, affecting cell-to-cell signaling in bacteria [56].

On the other hand, SeNPs assays against $A$. faecalis are limited.One of the few reports is by Hegerova et al. [57], who used SeNPs functionalized with carboxymethylcellulose, chemically synthesized and with an average size of $50-150 \mathrm{~nm}$, and they found highly effective activity against $A$. faecalis with a growth inhibition halo of $17 \mathrm{~mm}$ in diameter. Whereas, in this study, SeNPs obtained by biological synthesis with AsAc and marigold extracts, with a size of $40-60 \mathrm{~nm}$, were found to inhibit the growth of A. faecalis completely. According to these results, it could be considered that this bacterium presents high sensitivity to this type of antibacterial agent. In addition, it was observed that both methods of synthesis (chemical and biological) of SeNPs were effective in inhibiting bacterial growth and that the size of the NPs was not determinant in the antibacterial activity of these nanomaterials.

This work addresses the use of SeNPs as an antibacterial agent against nosocomial pathogenic bacteria, two of them of emerging type (S. marcescens and A. faecalis), where there is a low number of studies on the use of SeNPs as an alternative for their control, compared to the broad knowledge generated against other bacteria such as S. aureus or P. aeruginosa. Since a high antibacterial potential of the synthesized and characterized SeNPs was obtained, the subsequent studies have to be focused on performing biocompatibility assays in cell line models in vitro by different cytotoxicity assays 


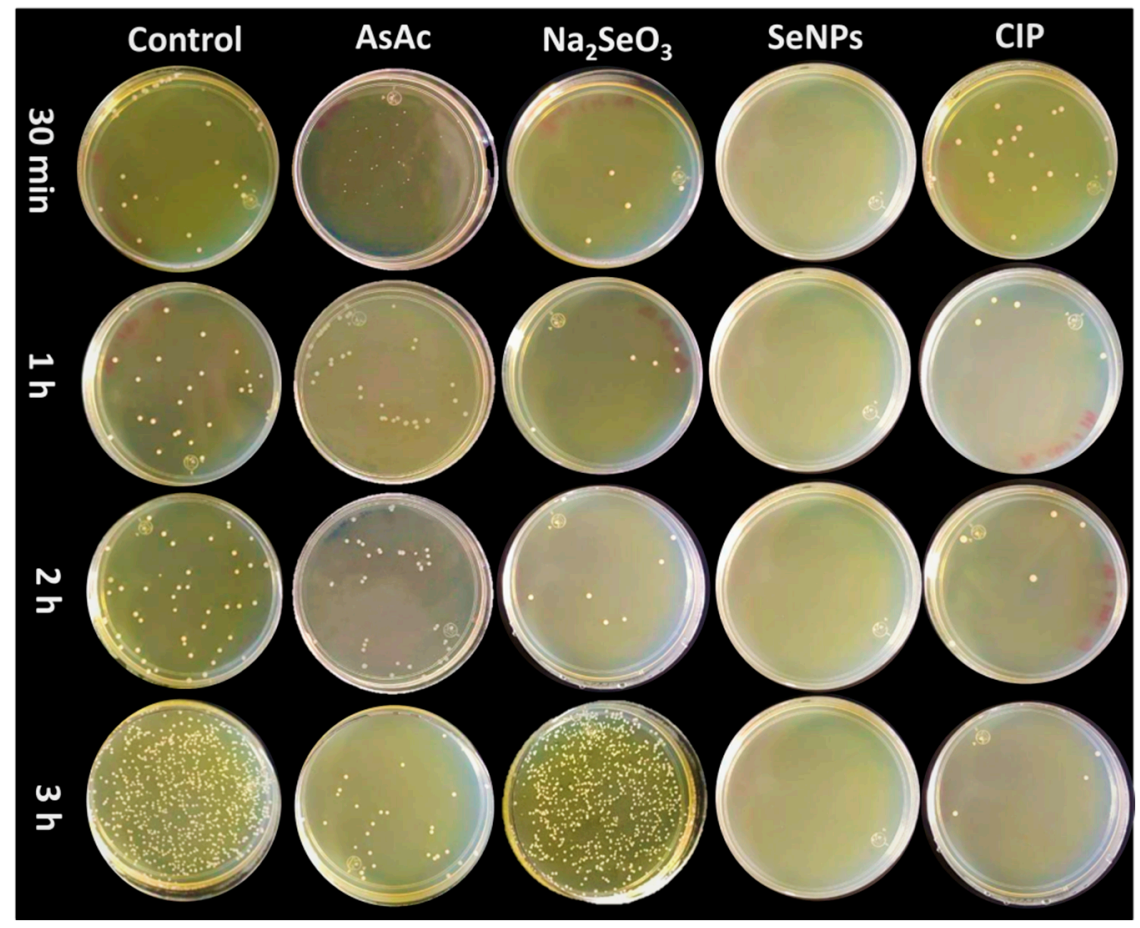

(a)

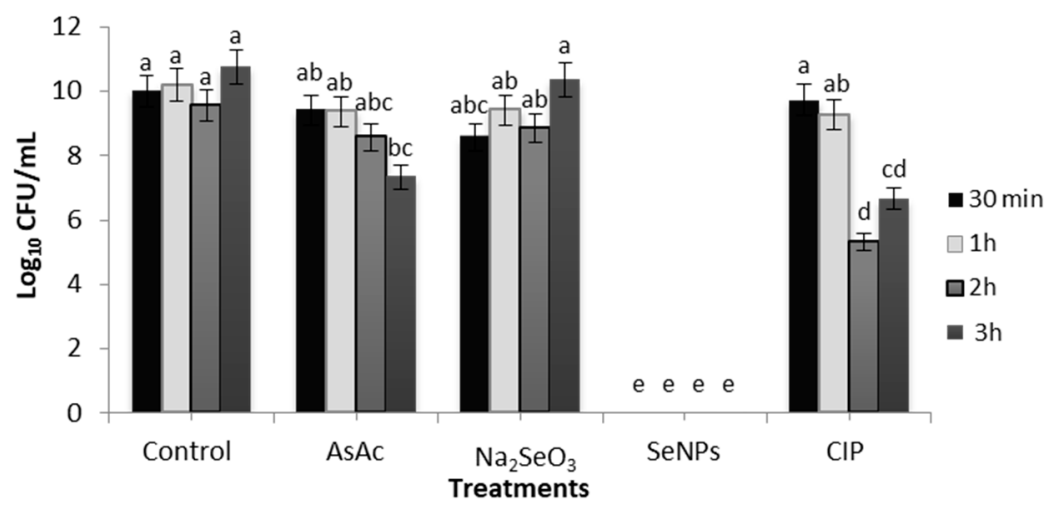

(b)

Figure 8. Antibacterial activity of SeNPs against A. faecalis. (a) Evaluation of antibacterial activity under different treatments and incubation times. (b) Effect of SeNPs on bacterial colony formation. Mean values \pm SE. Different letters denote statistically significant differences according to Duncan's test $(\alpha=0.05), p<0.0001$.

\subsection{Antioxidant Activity of SeNPs}

SeNPs biological activity is closely related to their antioxidant properties, and can be expressed as the relative measure of substance ability to prevent or retard substrate oxidation. SeNPs exhibit antioxidant effects by modulating the generation of ROS and reactive nitrogen species (RNS). These characteristics are exploited in biomedical applications, where SeNPs exhibit anti-inflammatory, anti-diabetic, antiviral, and fertility-enhancing properties [58]. Antioxidant compounds act through different mechanisms, which depend on the nature of the substance itself and its ability to interact with the medium in which it is dissolved [59]. Some chemical forms of Se, either organic (Se-Met and Se-Cys) or inorganic $\left(\mathrm{SeO}_{4}{ }^{2-}, \mathrm{SeO}_{3}{ }^{2-}, \mathrm{Se}^{2-}\right)$, have been reported to exhibit antioxidant activity [60]. 
In this aspect, it has been recognized that SeNPs have a better antioxidant capacity than the available inorganic forms of Se, and simultaneously the risk of toxicity is reduced [61] As reported by Vera et al. [62], it describes the ability of SeNPs to scavenge free radicals $\left(\mathrm{OH}^{\bullet}\right.$ and $\left.\mathrm{O}_{2}{ }^{\bullet-}\right)$.

On the other hand, it is known that various marigold extracts can present compounds with biological activities, including antioxidant activity [63]. This work evaluated the antioxidant activity of the Cof-Met extract, $\mathrm{Na}_{2} \mathrm{SeO}_{3}$, and $\mathrm{SeNPs}$ by three different techniques (DPPH, ABTS, and FRAP) (Figure 9). From the antioxidant activity of the Cof-Met extract, values of $54.2 \pm 3.1 \mu \mathrm{M}$ Trolox equivalent by $\mathrm{DPPH}, 79.7 \pm 3.1 \mu \mathrm{M}$ Trolox equivalent by $\mathrm{ABTS}$, and $79.7 \pm 6.7 \mu \mathrm{M}$ Trolox equivalent by FRAP were obtained. Interestingly, the antioxidant activity of the $\mathrm{Na}_{2} \mathrm{SeO}_{3}$ solution, at the concentration used for the synthesis of the NPs, only presented antioxidant activity with the ABTS technique (128.3 $\pm 6.6 \mu \mathrm{M}$ Trolox equivalent), with no values with DPPH or FRAP. The conditions of the FRAP (acid $\mathrm{pH}$ ) and DPPH (methanol) methods could affect the inhibition kinetics of the radical, generating a result ofundetected activity for $\mathrm{Na}_{2} \mathrm{SeO}_{3}$ in both assays. However, the ABTS technique is known to have less aggressive conditions (methanolic extract and less acidic $\mathrm{pH})$ that facilitate the detection of specific antioxidant molecules.

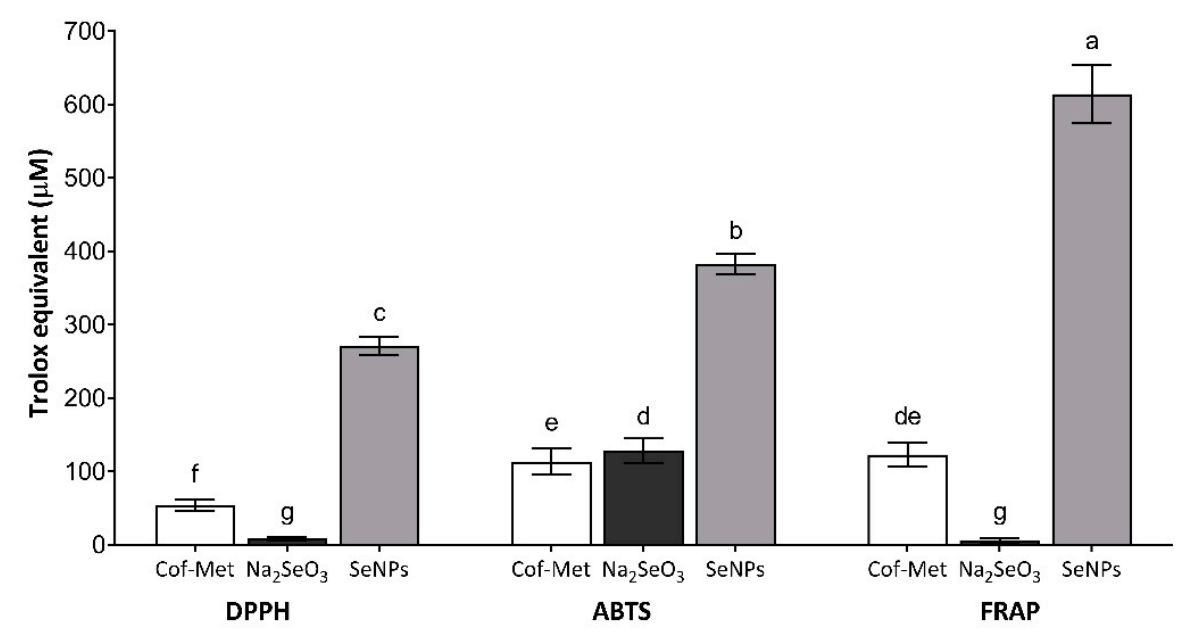

Figure 9. Antioxidant activity of SeNPs determined by DPPH (2,2-diphenyl-1-picrylhydrazyl), ABTS (2,2-azino-bis-3-ethylbenzothiazoline-6-sulphonic acid), and FRAP (Ferric reducing antioxidant power) assays. Cof-Met extract at the concentration used for the synthesis of SeNPs. $\mathrm{Na}_{2} \mathrm{SeO}_{3}$ solution at the concentration used for SeNPs synthesis. Mean values $\pm \mathrm{SE}$. Different letters denote statistically significant differences according to Duncan's test $(\alpha=0.05), p<0.0001$.

The SeNPs presented high values of antioxidant activity compared to the controls $\left(\mathrm{Na}_{2} \mathrm{SeO}_{3}\right.$ and Cof-Met extract). Likewise, significant differences were obtained between the three techniques used, with values of $271.0 \pm 5.1,382.5 \pm 5.6$, and $614.2 \pm 16.0 \mu \mathrm{M}$ Trolox equivalent for DPPH, ABTS, and FRAP, respectively. In the case of the antioxidant activity of SeNPs determined by FRAP, the value in $\mu \mathrm{M}$ of Trolox equivalent was 1.6 times higher than the ABTS method and 2.3 times higher than the DPPH method (Figure 9). These data may be striking, but they correspond to a phenomenon related to the high sensitivity of this system to determine, with more responsiveness, various antioxidant compounds whose potential is lower than the pair $\mathrm{Fe}^{3+}-\mathrm{Fe}^{2+}$, which is employed in the assembly of this technique [64]. It is important to note that the antioxidant activity of SeNPs could be affected by the size of the NPs. Studies have reported it based on the analysis of ROS production in human umbilical vein endothelial cells. It was argued that SeNPs biosynthesized with Pantoea agglomerans and L-cysteine, with sizes between 30 and $300 \mathrm{~nm}$, showed a particle size-dependent antioxidant capacity [65].

The results obtained from the measurement of antioxidant activity confirm that the possible mechanism of action, mediated by SeNPs, is more oriented towards an electron 
transfer (ET) reaction mechanism rather than a hydrogen atom transfer (HAT) mechanism. These results are in agreement with the studies performed by Zhai et al. [66] on SeNPs. Additionally, it is noted that the mechanisms of antioxidant activity present the opposite effect (there ishigher activity in DPPH vs. FRAP) when Se is in organic form, as reported by Alafeef et al. [67]. Finally, the results obtained present similar trends to those presented by other authors when comparing between $\mathrm{Na}_{2} \mathrm{SeO}_{3}$ controls vs. SeNPs, since SeNPs possess higher antioxidant activity than the inorganic Se source used for the synthesis of NPs [68].

\section{Materials and Methods}

\subsection{Plant Material Production}

The marigold plant material (leaves/stems and flowers) was obtained from the Costa Orange variety (Balls, Chicago, IL, USA). Seeds were sown in germination trays with commercial substrate and maintained at $25^{\circ} \mathrm{C}$ with a photoperiod of $14 \mathrm{~h}$ light and $10 \mathrm{~h}$ dark, watering three times a week and applying Hoagland nutrient solution $25 \%$ once a week. Thirty-day-old seedlings were transplanted into pots with commercial substrate and placed in a greenhouse with average conditions of $18.9^{\circ} \mathrm{C}, 70.4 \%$ relative humidity, and a photoperiod of $11 \mathrm{~h}$ light and $13 \mathrm{~h}$ dark. The plants were irrigated four times per week with running water and applied to Hoagland nutrient solution $100 \%$ once per week.

\subsection{Preparation of Plant Extracts and Their Fractions}

The extracts were prepared using marigold flowers as well as stems with leaves. The plant material obtained was frozen at $-80^{\circ} \mathrm{C}$ in an ultra-freezer (Forma 900-series, ThermoFisher, Waltham, MA, USA). Subsequently, the plant tissue was freeze-dried in a freeze-dryer (FreeZone, Labconco, Kansas City, MO, USA). Afterward, the plant samples were pulverized in an industrial mill (MF10BS1, IkaWerke, Wilmington, DE, USA) until a fine particle size was obtained. For flowers, extraction was performed with methanol $(\mathrm{MeOH})(1: 20 \mathrm{w} / \mathrm{v})$ assisted with sonication, using an ultrasonic bath of $100 \mathrm{~W}$ maximum rated output power and $42 \mathrm{kHz}$ frequency (2510R-DTH, Branson Ultrasonics, Danbury, USA) for three periods of $15 \mathrm{~min}$ at constant temperature $\left(25^{\circ} \mathrm{C}\right)$. For stems / leaves, they were macerated in $\mathrm{MeOH}(1: 10 w / v)$ for $24 \mathrm{~h}$ periods in triplicate. Finally, the solvent was evaporated under reduced pressure using a rotary evaporator (R-100, Buchi, Flawil, Switzerland) at a bath temperature of $40{ }^{\circ} \mathrm{C}$. The extracts obtained were stored at $4{ }^{\circ} \mathrm{C}$.

For fractionation of the methanolic flower extract, the first $37.0 \mathrm{~g}$ of the extract was dissolved in $370 \mathrm{~mL}$ of $\mathrm{MeOH}(1: 10 w / v)$. Subsequently, distilled water $(3: 2, v / v)$ was added. The resulting aqueous suspension was successively partitioned with hexane (twice; 1:1 v/v) and dichloromethane $(1: 1 \mathrm{v} / \mathrm{v})$. Finally, the aqueous fraction was the resultant of both fractionations. The solvents were evaporated at $40{ }^{\circ} \mathrm{C}$ in a rotary evaporator (R-100, Buchi, Flawil, Switzerland). The methanolic extracts of flowers, leaves/stems, and the resulting fractions were frozen at $-80{ }^{\circ} \mathrm{C}$ and then freeze-dried (FreeZone, Labconco, Kansas City, MO, USA) for 5 days.

\subsection{Obtaining and Characterization of Bacterial Strains}

Three strains of Gram-negative bacteria isolated from Phaseolus vulgaris seeds (S. marcescens and E. cloacae) and P. lunatus seeds (A. faecalis) were used to test both fractions' antibacterial activity of methanolic extracts of leaves/stems, flowers, and SeNPs. Morphological identification of the isolated bacterial strains was performed by Gram staining. For molecular identification, DNA extraction and amplification of the 16S rRNA fragment of ribosomal DNA was performed by polymerase chain reaction (PCR) in a thermal cycler (C1000 touch, Biorad, Hercules, CA, USA). Universal primers 27F $\left(5^{\prime}-\right.$ AGAGTTTGATCCTGGCTCAG-3') and 1492R (5'-GGTTACCTTGTTACGACTT-3 $\left.{ }^{\prime}\right)$ were used [69]. The PCR product obtained was purified using a commercial kit (Wizard ${ }^{\circledR} \mathrm{SV}$ Gel and PCR Clean-Up System, Promega, Madison, WI, USA), and the purified product was sent for sequencing (Macrogen Inc, Seul, South Korea). The sequences obtained were compared with the sequences deposited in the GenBank genomic database, and a 
comparison of multiple alignments was performed using the BLAST tool available at http:/ / www.ncbinlmnih.gov/, accessed on 14 September 2021. The consensus sequence of each strain was obtained and identified as S. marcescens (MK411566.1, 99.93\% identity), E. cloacae (MT509937.1, 99.70\% identity), and A. faecalis (CP033861.1, 99.29\% identity). Subsequently, the nucleotide consensus sequence was deposited in GenBank with the accession numbers MZ913727 (S. marcescens), MZ914398 (E. cloacae), and OK067254 (A. faecalis).

\subsection{Evaluation of the Antibacterial Activity of Plant Extracts and Their Fractions}

S. marcescens, E. cloacae, and A. faecalis bacteria were incubated in LB medium (SigmaAldrich, St. Louis, MO, USA) at $30{ }^{\circ} \mathrm{C}$ in a digital shaking incubator (LSI-3016R, Lab-Tech, Namyangju, Korea) for $24 \mathrm{~h}$.

Bacterial growth was adjusted to an optical density at $600 \mathrm{~nm}$ (OD600), using a spectrometer (Biophotometer, Eppendorf, Hamburg, Germany) to analyze antibacterial activity from marigold extracts and their fractions. Evaluation of antibacterial activity was carried out by the Kirby-Bauer disk diffusion method [70], using methanolic extracts of flowers (Cof-Met) and leaves/stems (Coht-Met), as well as the hexane (Cof-Hx), dichloromethane (Cof-Dcm),and aqueous (Cof-Aq) fractions. All treatments were evaluated at 200 and $300 \mathrm{mg} / \mathrm{mL}$, except Cof-Aq ( $300 \mathrm{mg} / \mathrm{mL}$ ). The positive control consisted of ciprofloxacin (CIP) $1 \mathrm{mg} / \mathrm{mL}$ for A. faecalis and gentamicin (Ge) $1 \mathrm{mg} / \mathrm{mL}$ for S. marcescens and E. cloacae. $\mathrm{MeOH}$, water $\left(\mathrm{H}_{2} \mathrm{O}\right)$, or ethyl acetate (AcEt) were included as negative controls. Petri dishes with nutrient agar were inoculated with $100 \mu \mathrm{L}$ of bacterial growth at $\mathrm{OD}_{600}$, previously mixed in $4 \mathrm{~mL}$ of $50 \%$ nutrient agar. Once the Petri dishes were inoculated, filter paper discs $(6 \mathrm{~mm})$ impregnated with $20 \mu \mathrm{L}$ of the different treatments were placed. Petri dishes were incubated at $30^{\circ} \mathrm{C}$ in a natural convection incubator (DBO-13, Prendo, Puebla, Mexico) for $24 \mathrm{~h}$. Finally, the inhibition halo was measured. Each test was performed in triplicate with six replicates.

\subsection{SeNPs Synthesis}

The colloidal solution of SeNPs was obtained by the green synthesis method by reduction of sodium selenite $\left(\mathrm{Na}_{2} \mathrm{SeO}_{3}\right.$ ) (Sigma-Aldrich, St. Louis, MO, USA), using $10 \mathrm{~mL}$ $(10 \mathrm{mM})$, to which $3.5 \mathrm{~mL}$ of ascorbic acid (AsAc) $(40 \mathrm{mM})$ and $120 \mu \mathrm{L}$ of methanolic extract of marigold flowers (Cof-Met) $(100 \mathrm{mg} / \mathrm{mL})$ were added. The reaction was carried out under magnetic stirring at $1150 \mathrm{rpm}$ and $40^{\circ} \mathrm{C}$ for $30 \mathrm{~min}$. The reaction was completed after $24 \mathrm{~h}$ in darknesswithout magnetic stirring at $4{ }^{\circ} \mathrm{C}$.

\subsection{SeNPs Characterization}

The determination of the absorption spectrum and the stability of the SeNPs were obtained using a UV-vis spectrophotometer (Genesis 10S UV-vis, Thermo Scientific, Carlsbad, CA, USA) in the wavelength range from 200 to $400 \mathrm{~nm}$ with a path length of $1 \mathrm{~cm}$. The size and shape of the SeNPs were determined by SEM (MIRA 3 LMU, TESCAN, Brno, Czech Republic) at $20 \mathrm{kV}$ and TEM (JSM-1010, JEOL, Tokyo, Japan) at $80 \mathrm{kV}$. A descriptive statistical analysis was performed on the size distribution of SeNPs from three independent assays. A mean of $53.30 \mathrm{~nm}$, median of $48.72 \mathrm{~nm}$, mode of $48.72 \mathrm{~nm}$, standard error of 3.49 , as well as Kurtosis coefficient (0.1011) and skewness coefficient (0.8387) close to zero were obtained. From these data, the normal distribution plot (Gaussian distribution) of the SeNPs size was plotted.Surface microanalysis microprobe EDX spectroscopy (Quantax EDS, Bruker, Billerica, MA, USA) was used to detect the elemental composition of the SeNPs. The functional groups present in the extracts and the resulting SeNPs were determined by FTIR spectrophotometry (iS10 FTIR, Thermo Scientific, Waltham, MA, USA).

\subsection{Evaluation of the Antibacterial Activity of SeNPs}

From axenic cultures, a suspension of each bacterial strain was prepared from an individual colony that was inoculated in a tube with $5 \mathrm{~mL}$ of nutrient broth (Difco, Detroit, USA) for S. marcescens and E. cloacae, while A. faecalis was inoculated in $5 \mathrm{~mL}$ of LB broth 
(Sigma-Aldrich, St. Louis, MO, USA). The cultures were incubated at $37^{\circ} \mathrm{C}$ for $24 \mathrm{~h}$ in an incubator (Incucell IC 55, MMM Group, Munich, Germany). After the incubation time had elapsed, an inoculum was prepared with peptonized water (Difco, Detroit, USA) by adjusting to a concentration of 0.5 on the McFarland scale using a densitometer (Densimat, Biomérieux, Lyon, France), equivalent to $1 \times 10^{8} \mathrm{CFU} / \mathrm{mL}$. Five inoculums of each strain were prepared according to the treatments to be evaluated.

For the evaluation of antibacterial activity, each of $S$. marcescens, E. cloacae, and A. faecalis inoculums were treated with SeNPs $(7.3 \mathrm{mM})$, AsAc $(10.27 \mathrm{mM}), \mathrm{Na}_{2} \mathrm{SeO}_{3}$ $(7.3 \mathrm{mM})$, and CIP $(1 \mathrm{mg} / \mathrm{mL})$. An untreated inoculum was considered as a negative control. Inoculums with each of the treatments were incubated for 30, 60, 120, and $180 \mathrm{~min}$ at $37^{\circ} \mathrm{C}$. After the incubation time, a $100 \mu \mathrm{L}$ aliquot of each treatment was taken and plated in duplicate on nutrient agar Petri dishes using the surface spreading technique with a Drigalsky loop. Petri dishes were incubated at $37^{\circ} \mathrm{C}$ in a natural convection incubator (Incucell IC 55, MMM group, Munich, Germany) for $24 \mathrm{~h}$. For all treatments, dilutions were performed ( 7 serial dilutions 1/10), and from the $1 \times 10^{-7}$ dilution, an aliquot of $100 \mu \mathrm{L}$ was taken and plated as previously described. Finally, countable bacterial colonies (25-250 CFU) were recorded, and the results were reported as the average CFU/mL of three independent assays.

\subsection{Antioxidant Activity Evaluation of SeNPS}

The ABTS Assay $\left(\mathrm{ABTS}^{+}\right.$) was conducted as described by Re et al. [71] at $750 \mathrm{~nm}$, and Flores et al. [72]. A solution of ABTS was prepared by diluting $96 \mathrm{mg}$ of ABTS with $25 \mathrm{~mL}$ of water; subsequently, $26 \mathrm{mg}$ of potassium persulfate wasadded and mixed by stirring. This solution was stored for $16 \mathrm{~h}$ in the dark. At the end of this period, the solution was adjusted to an optical density of 0.7 at $754 \mathrm{~nm}$. A standard curve $(0-400 \mu \mathrm{g} / \mathrm{mL})$ was prepared with Trolox. The reaction was carried out in a microplate, mixing $20 \mu \mathrm{L}$ of the sample with $280 \mu \mathrm{L}$ of ABTS. Measurements were performed in triplicate at $754 \mathrm{~nm}$ for $15 \mathrm{~min}$.

The Ferrous reducing antioxidant power (FRAP) assay of samples was evaluated by the method of Oyaizu [73]. The $\mathrm{Fe}^{2+}$ was monitored by measuring the formation of Perl's Prussian blue at $700 \mathrm{~nm}$. Briefly, the FRAP reagent was prepared by mixing acetate buffer (300 mM, pH 3.6), a solution of $10 \mathrm{mM}$ 2,4,6-Tripyridyl-s-triazine(TPTZ) in $40 \mathrm{mM} \mathrm{HCl}$, and $20 \mathrm{mM} \mathrm{FeCl}^{3+}$ at 10:1:1 $(v / v / v)$. The reagent $(3.4 \mu \mathrm{L})$ and sample solutions $(100 \mu \mathrm{L})$ were added to each well and mixed thoroughly. The absorbance was taken at $593 \mathrm{~nm}$ after $15 \mathrm{~min}$. A standard curve was prepared using different concentrations of Trolox.

The DPPH assay was performed according to Desmarchelier et al.'s [74] protocol. In brief, a $1.6 \mathrm{mM}$ solution of DPPH was prepared. The calibration curve was performed in the range of $0-400 \mu \mathrm{g} / \mathrm{mL}$ using Trolox as a reference. Twenty $\mu \mathrm{L}$ of the samples were added toa micro-plate intriplicate, and $280 \mu \mathrm{L}$ of the DPPH solution was added subsequently, and readings were measured at $515 \mathrm{~nm}$ after $15 \mathrm{~min}$ of reaction.

All results of antioxidant activities were expressed as $\mu \mathrm{M}$ Trolox equivalent/ mL solution.

\subsection{Statistical Analysis}

A two-way analysis of variance (ANOVA) was performed and the difference between mean values was obtained with the procedures of SAS 9.1 statistical software (SAS Institute, Cary NC, USA), using Duncan's multiple range test with a significance level of $p<0.05$.

\section{Conclusions}

Methanolic extracts of marigold leaves/stems and flowers and their fractions were evaluated, and antibacterial activity was obtained using Coht-Met and Cof-Met extracts against $S$. marcescens.

SeNPs were obtained by green synthesis using AsAc and Cof-Met extract. Their characterization by UV-vis, FTIR, SEM, EDX, and TEM showed NPs with a spherical shape and 
a 40-60 nm size range. The antibacterial activity of the extract, $\mathrm{AsAc}$, and $\mathrm{Na}_{2} \mathrm{SeO}_{3}$ was enhanced by producing the SeNPs, which significantly inhibited the growth of $S$. marcescens, E. cloacae, and A. faecalis bacterial strains. The results of the antibacterial assays demonstrated that the SeNPs presented better antibacterial activity, at different incubation times, compared to the antibiotic CIP. The application of $\mathrm{Na}_{2} \mathrm{SeO}_{3}$ and AsAc showed an inhibitory effect on the growth of bacterial colonies. However, this activity was lower than that obtained with SeNPs. The importance of this study lies in the possibility that SeNPs could be an effective alternative for the control of these bacterial strains, whichare associated with hospital infections, are considered of clinical and epidemiological importance, and are classified as resistant to antibiotics. Additionally, it was found that SeNPs present higher antioxidant activity than Cof-Met extract and $\mathrm{Na}_{2} \mathrm{SeO}_{3}$, which could be exploited for the treatment of bacterial disease affections together with their antibacterial activity. Further research is needed to understand the mechanism of action of SeNPs on bacteria, the modes of delivery to the target sites, and the possible toxic effects on living organisms.

Author Contributions: Conceptualization, J.A.H.-D., J.J.G.-G., J.A.-Q., and S.G.-M.; Formal analysis, A.Z.-O., J.A.-Q., G.V.-J., and S.G.-M.; Funding acquisition, J.M.L.-M., and S.G.-M.; Investigation, J.A.H.-D., J.J.G.-G., J.C.L.-V., and S.G.-M.; Methodology, J.A.H.-D., J.J.G.-G., J.M.L.-M., A.Z.-O., J.A.-Q., and G.V.-J.; Project administration, J.M.L.-M., and S.G.-M.; Supervision, J.M.L.-M., A.Z.-O., J.A.-Q., J.C.L.-V., and S.G.-M.; Validation, J.M.L.-M., A.Z.-O., J.A.-Q., and G.V.-J.; Visualization, J.A.H.-D., J.J.G.-G., J.M.L.-M., A.Z.-O., J.A.-Q., J.C.L.-V., and S.G.-M.; Writing-original draft, J.A.H.-D., J.J.G.-G., G.V.-J., and S.G.-M.; Writing-review and editing, S.G.-M. All authors have read and agreed to the published version of the manuscript.

Funding: This research was funded by CONACYT-Mexico, grants numbers: 2928-2016 (FOINS-PN), 292474-2017 (FORDECYT project), and 315918-2021 (PLANTECC National Laboratory).

Acknowledgments: Authors J.A.H.-D (717214) and J.J.G.G (717217) want to thank CONACYTMexico for the Masters scholarship granted. The authors thank the University Center for Exact Sciences and Engineering (CUCEI) and the University Center of Tonala (CUTONALA) for the facilities granted for the use of equipment and laboratories.

Conflicts of Interest: The authors declare no conflict of interest.

Sample Availability: Samples of the bacterial strains are available from the authors.

\section{References}

1. Bayda, S.; Adeel, M.; Tuccinardi, T.; Cordani, M.; Rizzolio, F. The History of nanoscience and nanotechnology: From chemicalphysical applications to nanomedicine. Molecules 2019, 25, 112. [CrossRef] [PubMed]

2. Pelyhe, C.; Mézes, M. Myths and facts about the effects of nano-selenium in farm animals mini-review. Eur. Chem. Bull. 2013, 2, 1049-1052.

3. Moghimi, S.M.; Hunter, A.C.; Murray, J.C. Nanomedicine: Current status and future prospects. FASEB J. 2005, 19, 311-330. [CrossRef] [PubMed]

4. Patra, J.K.; Das, G.; Fraceto, L.F.; Campos, E.; Rodriguez-Torres, M.; Acosta-Torres, L.S.; Diaz-Torres, L.A.; Grillo, R.; Swamy, M.K.; Sharma, S.; et al. Nano based drug delivery systems: Recent developments and future prospects. J. Nanobiotechnol. 2018, 16, 71. [CrossRef]

5. Garza-García, J.J.O.; Hernández-Díaz, J.A.; Zamudio-Ojeda, A.; León-Morales, J.M.; Guerrero-Guzmán, A.; Sánchez-Chiprés, D.R.; López-Velázquez, J.C.; García-Morales, S. The role of selenium nanoparticles in agriculture and food technology. Biol. Trace Elem. Res. 2021. [CrossRef]

6. Rayman, M.P. The importance of selenium to human health. Lancet. 2000, 365, 233-241. [CrossRef]

7. Khurana, S.; Tekula, M.A.; Saifi, P.; Venkatesh, P.; Godugu, C. Therapeutic applications of selenium nanoparticle. Biomed. Pharmacother. 2019, 111, 802-812. [CrossRef] [PubMed]

8. Ikram, M.; Javed, B.; Raja, N.I.; Mashwani, Z.U. Biomedical potential of plant-based selenium nanoparticles: A comprehensive review on therapeutic and mechanistic aspects. Int. J. Nanomed. 2021, 16, 249-268. [CrossRef] [PubMed]

9. Efstratiou, E.; Hussain, A.I.; Nigam, P.S.; Moore, J.E.; Ayub, M.A.; Rao, J.R. Antimicrobial activity of Calendula officinalis petal extracts against fungi, as well as Gram-negative and Gram-positive clinical pathogens. Complement. Ther. Clin. Pract. 2012, 18, 173-176. [CrossRef]

10. Ram, S.; Mitra, M.; Shah, F.; Tirkey, S.R.; Mishra, S. Bacteria as an alternate biofactory for carotenoid production: A review of its applications, opportunities and challenges. J. Funct. Foods. 2020, 67, 103867. [CrossRef] 
11. Olfati, A.; Kahrizi, D.; Jalal Balaky, S.T.; Rouhallah Sharifi, M.B.; ElahehDarvishi, T. Green synthesis of nanoparticles using Calendula officinalis extract from silver sulfate and their antibacterial effects on Pectobacterium caratovorum. Inorg. Chem. Commun. 2021, 125, 108439. [CrossRef]

12. Nandini, B.; Hariprasad, P.; Prakash, H.S.; Shetty, H.S.; Geetha, N. Trichogenic-selenium nanoparticles enhance disease suppressive ability of Trichoderma against downy mildew disease caused by Sclerospora graminicola in pearl millet. Sci. Rep. 2017, 7, 2612 [CrossRef] [PubMed]

13. Shahabadi, N.; Zendehcheshm, S.; Khademi, F. Selenium nanoparticles: Synthesis, in-vitro cytotoxicity, antioxidant activity and interaction studies with ct-DNA and HSA, HHb and Cyt c serum proteins. Biotechnol. Rep. 2021, 30, e00615. [CrossRef]

14. Vahdati, M.; Tohidi Moghadam, T. Synthesis and characterization of selenium nanoparticles-lysozyme nanohybrid system with synergistic antibacterial properties. Sci. Rep. 2020, 10, 510. [CrossRef] [PubMed]

15. Fierascu, I.; Bunghez, I.; Fierascu, C.R.; Ion, R.; Romania, B. Characterization and antioxidant activity of phytosynthesised silver nanoparticles using Calendula officinalis extract. Farmacia-Bucuresti. 2014, 62, 129-136.

16. Fardsadegh, B.; Vaghari, H.; Mohammad-Jafari, R.; Najian, Y.; Jafarizadeh-Malmiri, H. Biosynthesis, characterization and antimicrobial activities assessment of fabricated selenium nanoparticles using Pelargonium zonale leaf extract. Green Process. Synth. 2019, 8, 191-198. [CrossRef]

17. Filipović, N.; Ušjak, D.; Milenković, M.T.; Zheng, K.; Liverani, L.; Boccaccini, A.R.; Stevanović, M.M. Comparative study of the antimicrobial activity of selenium nanoparticles with different surface chemistry and structure. Front. Bioeng. Biotechnol. 2021, 8, 624621. [CrossRef]

18. Dhanjal, S.; Cameotra, S. Aerobic biogenesis of selenium nanospheres by Bacillus cereus isolated from coalmine soil. Microb. Cell Factories 2010, 9, 52. [CrossRef]

19. Asano, N.; Lu, J.; Asahina, S.; Takami, S. Direct observation techniques using scanning electron microscope for hydrothermally synthesized nanocrystals and nanoclusters. Nanomaterials 2021, 11, 908. [CrossRef]

20. Qu, Y.; Yang, H.; Yang, N.; Fan, Y.; Zhu, H.; Zou, G. The effect of reaction temperature on the particle size, structure and magnetic properties of coprecipitated $\mathrm{CoFe}_{2} \mathrm{O}_{4}$ nanoparticles. Mater. Lett. 2006, 60, 3548-3552. [CrossRef]

21. Ankamwar, B.; Damle, C.; Ahmad, A.; Sastry, M. Biosynthesis of gold and silver nanoparticles using Emblica Officinalis fruit extract, their phase transfer and transmetallation in an organic solution. J. Nanosci. Nanotechnol. 2005, 5, 1665-1671. [CrossRef]

22. Cittrarasu, V.; Kaliannan, D.; Dharman, K.; Maluventhen, V.; Easwaran, M.; Liu, W.C.; Balasubramanian, B.; Arumugam, M. Green synthesis of selenium nanoparticles mediated from Ceropegia bulbosa Roxb extract and its cytotoxicity, antimicrobial, mosquitocidal and photocatalytic activities. Sci. Rep. 2021, 11, 1032. [CrossRef]

23. Pirtarighat, S.; Ghannadnia, M.; Baghshahi, S. Green synthesis of silver nanoparticles using the plant extract of Salvia spinosa grown in vitro and their antibacterial activity assessment. J. Nanostruct. Chem. 2019, 9, 1-9. [CrossRef]

24. Arockiya Aarthi Rajathi, F.; Arumugam, R.; Saravanan, S.; Anantharaman, P. Phytofabrication of gold nanoparticles assisted by leaves of Suaeda monoica and its free radical scavenging property. J. Photochem. Photobiol. B 2014, 135, 75-80. [CrossRef]

25. Zhuang, J.; Li, M.; Pu, Y.; Ragauskas, A.J.; Yoo, C.G. Observation of potential contaminants in processed biomass using fourier transform infrared spectroscopy. Appl. Sci. 2020, 10, 4345. [CrossRef]

26. Santhoshkumar, J.; Rajeshkumar, S.; Venkat Kumar, S. Phyto-assisted synthesis, characterization and applications of gold Nanoparticles-A review. Biochem. Biophys. Rep. 2017, 11, 46-57. [CrossRef]

27. Kannan, S.; Mohanraj, K.; Prabhu, K.; Barathan, S.; Sivakumar, G. Synthesis of selenium nanorods with assistance of biomolecule. Bull. Mater. Sci. 2014, 37, 1631-1635. [CrossRef]

28. Balashanmugam, P.; Pudupalayam, T.K. Biosynthesis characterization of silver nanoparticles using Cassia roxburghii DC. aqueous extract, and coated on cotton cloth for effective antibacterial activity. Int. J. Nanomed. 2015, 10, 87-97. [CrossRef] [PubMed]

29. Stella, C.; Soundararajan, N.; Ramachandran, K. Structural, optical, and magnetic properties of $\mathrm{Mn}_{\text {and }} \mathrm{Fe}_{-} \mathrm{doped} \mathrm{Co}_{3} \mathrm{O}_{4}$ nanoparticles. AIP Adv. 2015, 5, 087104. [CrossRef]

30. Al Jahdaly, B.A.; Al-Radadi, N.S.; Eldin, G.M.G.; Almahri, A.; Ahmed, M.K.; Shoueir, K.; Janowska, I. Selenium nanoparticles synthesized using an eco-friendly method: Dye decolorization from aqueous solutions, cell viability, antioxidant, and antibacterial effectiveness. J. Mater. Res. Technol. 2021, 11, 85-97. [CrossRef]

31. Saidin, S.; Jumat, M.A.; Mohd, A.; Nur, A.A.; Saleh, A.; Abdullah, S. Organic and inorganic antibacterial approaches in combating bacterial infection for biomedical application. Mater. Sci. Eng. C Mater. Biol. Appl. 2021, 118, 111382. [CrossRef]

32. Kim, S.B.; Jeon, Y.D.; Kim, J.H.; Kim, J.K.; Ann, H.W.; Choi, H.; Kim, M.H.; Song, J.E.; Ahn, J.Y.; Jeong, S.J.; et al. Risk factors for mortality in patients with Serratia marcescens bacteremia. Yonsei Med, J. 2015, 56, 348-354. [CrossRef]

33. Chiang, P.C.; Wu, T.L.; Kuo, A.J.; Huang, Y.C.; Chung, T.Y.; Lin, C.S.; Su, L.H. Outbreak of Serratia marcescens postsurgical bloodstream infection due to contaminated intravenous pain control fluids. Int. J. Infect. Dis. 2013, 17, e718-e722. [CrossRef] [PubMed]

34. Jarvis, E.M.; Hawley, C.M.; McDonald, S.P.; Brown, F.G.; Rosman, J.B.; Wiggins, K.J.; Bannister, K.M.; Johnson, D.W. Predictors, treatment, and outcomes of non-Pseudomonas Gram-negative peritonitis. Kidney Int. 2010, 78, 408-414. [CrossRef] [PubMed]

35. Menon, S.; Agarwal, H.; Rajeshkumar, S.; Jacquline, R.P.; Shanmugam, V.K. Investigating the antimicrobial activities of the biosynthesized selenium nanoparticles and its statistical analysis. Bionanoscience 2020, 10, 122-135. [CrossRef]

36. Jeong, Y.; Lim, D.W.; Choi, J. Assessment of size-dependent antimicrobial and cytotoxic properties of silver nanoparticles. Adv. Mater. Sci. Eng. 2014, 2014, 763807. [CrossRef] 
37. Gunti, L.; Dass, R.S.; Kalagatur, N.K. Phytofabrication of selenium nanoparticles from Emblica officinalis fruit extract and exploring its biopotential applications: Antioxidant, antimicrobial, and biocompatibility. Front. Microbiol. 2019, 10, 931. [CrossRef]

38. Bhave, P.; Tregaskis, P.; Walker, R.; Wilson, S. Intraperitoneal meropenem for peritoneal dialysis peritonitis with Serratia marcescens immediately on commencing dialysis. New Microbes New Infect. 2016, 10, 84-86. [CrossRef]

39. Khanna, A.; Khanna, M.; Aggarwal, A. Serratia marcescens-A rare opportunistic nosocomial pathogen and measures to limit its spread in hospitalized patients. J. Clin. Diagn. Res. 2013, 7, 243-246.

40. Ravindran, D.; Ramanathan, S.; Arunachalam, K.; Jeyaraj, G.P.; Shunmugiah, K.P.; Arumugam, V.R. Phytosynthesized silver nanoparticles as antiquorum sensing and antibiofilm agent against the nosocomial pathogen Serratia marcescens: An in vitro study. J. Appl. Microbiol. 2018, 124, 1425-1440. [CrossRef]

41. Ghada, M.K.; Bahig, A.E. Antimicrobial and antibiofilm effects of selenium nanoparticles on some foodborne pathogens. LWT-Food Sci. Technol. 2015, 63, 1001-1007.

42. Fernández, L.; Hancock, R.E. Adaptive and mutational resistance: Role of porins and efflux pumps in drug resistance. Clin. Microbiol. Rev. 2012, 25, 661-681. [CrossRef]

43. Rudramurthy, G.; Swamy, M.; Sinniah, U.; Ghasemzadeh, A. Nanoparticles: Alternatives against drug-resistant pathogenic microbes. Molecules 2016, 21, 836. [CrossRef] [PubMed]

44. Hernández-Díaz, J.A.; Garza-García, J.J.; Zamudio-Ojeda, A.; León-Morales, J.M.; López-Velázquez, J.C.; García-Morales, S. Plant-mediated synthesis of nanoparticles and their antimicrobial activity against phytopathogens. J. Sci. Food Agric. 2021, 101, 1270-1287. [CrossRef] [PubMed]

45. Zawadzka, A.M.; Crawford, R.L.; Paszczynski, A.J. Pyridine-2,6-bis(thiocarboxylic acid) produced by Pseudomonas stutzeri KC reduces and precipitates selenium and tellurium oxyanions. Appl. Environ. Microbiol. 2006, 72, 3119-3129. [CrossRef] [PubMed]

46. Xu, C.L.; Wang, Y.Z.; Jin, M.L.; Yang, X.Q. Preparation, characterization and immunomodulatory activity of selenium-enriched exopolysaccharide produced by bacterium Enterobacter cloacae Z0206. Bioresour. Technol. 2009, 100, 2095-2097. [CrossRef] [PubMed]

47. Fernández-Llamosas, H.; Castro, L.; Blázquez, M.L.; Díaz, E.; Carmona, M. Biosynthesis of selenium nanoparticles by Azoarcus sp. CIB. Microb. Cell Fact. 2016, 15, 109. [CrossRef] [PubMed]

48. Huang, C. Extensively drug-resistant Alcaligenes faecalis infection. BMC Infect. Dis. 2020, 20, 833. [CrossRef] [PubMed]

49. Hasan, M.J.; Nizhu, L.N.; Rabbani, R. Bloodstream infection with pandrug-resistant Alcaligenes faecalis treated with double-dose of tigecycline. IDCases 2019, 18, e00600. [CrossRef] [PubMed]

50. Tosun, M.N.; Demirel Zorba, N.N.; Yüceer, Y. The anti-quorum sensing and antitumor activity of Prunella vulgaris, Sambucus nigra, Calendula officinalis: Potential use in food industry: Potential use in food industry. J. Microbiol. Biotechnol. Food. Sci. 2021, 10, e2774.

51. Prateeksha; Singh, B.R.; Shoeb, M.; Sharma, S.; Naqvi, A.H.; Gupta, V.K.; Singh, B.N. Scaffold of selenium nanovectors and honey phytochemicals for inhibition of Pseudomonas aeruginosa quorum sensing and biofilm formation. Front. Cell. Infect. Microbiol. 2017, 7, 93. [CrossRef] [PubMed]

52. Lahiri, D.; Nag, M.; Dutta, B.; Mukherjee, I.; Ghosh, S.; Dey, A.; Ray, R.R. Catechin as the most efficient bioactive compound from Azadirachta indica with antibiofilm and anti-quorum sensing activities against dental biofilm: An in vitro and in silico study. Appl. Biochem. Biotechnol. 2021, 193, 1617-1630. [CrossRef] [PubMed]

53. Gómez-Gómez, B.; Arregui, L.; Serrano, S.; Santos, A.; Pérez-Corona, M.T.; Madrid, Y. Selenium and tellurium-based nanoparticles as interfering factors on Quorum sensing-regulated processes: Violacein production and bacterial biofilm formation. Metallomics 2019, 11, 1104-1114. [CrossRef]

54. Escobar-Ramírez, M.C.; Castañeda-Ovando, A.; Pérez-Escalante, E.; Rodríguez-Serrano, G.M.; Ramírez-Moreno, E.; Quintero-Lira, A.; Contreras-López, E.; Añorve-Morga, J.; Jaimez-Ordaz, J.; González-Olivares, L.G. Antimicrobial activity of Se-nanoparticles from bacterial biotransformation. Fermentation 2021, 7, 130. [CrossRef]

55. Gnarpe, H.; Michaelsson, M.; Dreborg, S. The in vitro effect of ascorbic acid on the bacterial growth in urine. Acta Pathol. Microbiol. Scand. 1968, 74, 41-50. [CrossRef]

56. Novak, J.S.; Fratamico, P.M. Evaluation of ascorbic acid as a quorum-sensing analogue to control growth, sporulation, and enterotoxin production in Clostridium perfringens. J. Food Sci. 2004, 69, FMS72-FMS78. [CrossRef]

57. Hegerova, D.; Vesely, R.; Cihalova, K.; Kopel, P.; Milosavljevic, V.; Heger, Z.; Hynek, D.; Guran, R.; Vaculovicova, M.; Sedlacek, P.; et al. Antimicrobial agent based on selenium nanoparticles and carboxymethyl cellulose for the treatment of bacterial infections. J. Biomed. Nanotechnol. 2017, 13, 767-777. [CrossRef]

58. Kondaparthi, P.; Flora, S.J.S.; Naqvi, S. Selenium nanoparticles: An insight on its pro-oxidant and antioxidant properties. Front. Nanosci. Nanotechnol. 2019, 6, 1-5. [CrossRef]

59. Apak, R.; Özyürek, M.; Guclu, K.; Capanoglu, E. Antioxidant activity/capacity measurement: I. Classification, physico-chemical principles, mechanisms and electron transfer (ET)-based assays. J. Agric. Food. Chem. 2016, 64, 997-1027. [CrossRef] [PubMed]

60. Ramoutar, R.R.; Brumaghim, J.L. Effects of inorganic selenium compounds on oxidative DNA damage. J. Inorg. Biochem. 2007, 101, 1028-1035. [CrossRef] [PubMed]

61. Bhattacharjee, A.; Basu, A.; Bhattacharya, S. Selenium nanoparticles are less toxic than inorganic and organic selenium to mice in vivo. Nucleus 2019, 62, 259-268. [CrossRef]

62. Vera, P.; Echegoyen, Y.; Canellas, E.; Nerín, C.; Palomo, M.; Madrid, Y.; Cámara, C. Nano selenium as antioxidant agent in a multilayer food packaging material. Anal. Bioanal. Chem. 2016, 408, 6659-6670. [CrossRef] 
63. Preethi, K.C.; Girija, K.; Ramadasan, K. Antioxidant potential of an extract of Calendula officinalis. Flowers in vitro. and in vivo. Pharm. Biol. 2006, 44, 691-697. [CrossRef]

64. Bedlovičová, Z.; Imrich, S.; Matej, B.; Aneta, S. A Brief overview on antioxidant activity determination of silver nanoparticles. Molecules 2020, 25, 3191. [CrossRef] [PubMed]

65. Torres, S.K.; Campos, V.L.; León, C.G.; Rodriguez-Llamazares, S.M.; Rojas, S.M.; Gonzalez, M.; Smith, C.; Mondaca, M.A. Biosynthesis of selenium nanoparticles by Pantoeaagglomerans and their antioxidant activity. J. Nanopart. Res. 2012, $14,1236$. [CrossRef]

66. Zhai, X.; Zhang, C.; Zhao, G.; Stoll, S.; Ren, F.; Leng, X. Antioxidant capacities of the selenium nanoparticles stabilized by chitosan. J. Nanobiotechnol. 2017, 15, 4. [CrossRef]

67. Alafeef, A.K.; Ariffin, F.; Zulkurnain, M. Organic selenium as antioxidant additive in mitigating acrylamide in coffee beans roasted via conventional and superheated steam. Foods 2020, 9, 1197. [CrossRef] [PubMed]

68. Alipour, S.; Kalari, S.; HosseinMorowvat, M.; Sabahi, Z.; Dehshahri, A. Green synthesis of selenium nanoparticles by cyanobacterium Spirulina platensis (abdf2224): Cultivation condition quality controls. Biomed. Res. Int. 2021, 6635297.

69. Wu, C.F.; Xu, X.M.; Zhu, Q.; Deng, M.C.; Feng, L.; Peng, J.; Yuan, J.P.; Wang, J.H. An effective method for the detoxification of cyanide-rich waste water by Bacillus sp. CN-22. Appl. Microbiol. Biotechnol. 2014, 98, 3801-3807. [CrossRef]

70. Al Laham, S.A.; Al Fadel, F.M. Antibacterial activity of various plants extracts against antibiotic-resistant Aeromonas hydrophila. Jundishapur, J. Microbiol. 2014, 7, e11370. [CrossRef]

71. Re, R.; Pellegrini, N.; Proteggente, A.; Pannala, A.; Yang, M.; Rice-Evans, C. Antioxidant activity applying an improved ABTS radical cation decolorization assay. Free. Radic. Biol. Med. 1999, 26, 1231-1237. [CrossRef]

72. Flores, D.R.; Casados, L.E.; Velasco, S.F.; Ramírez, A.C.; Velázquez, G. Comparative study of composition, antioxidant and antimicrobial activity of two adult edible insects from Tenebrionidae family. BMC Chem. 2020, 14, 55. [CrossRef] [PubMed]

73. Oyaizu, M. Studies on products of browning reactions: Antioxidative activities of product of browning reaction prepared from glucosamine. Jap. J. Nutr. 1986, 44, 307-315. [CrossRef]

74. Desmarchelier, C.; Bermudez, M.J.N.; Coussio, J.; Ciccia, G.; Boveris, A. Antioxidant and prooxidant activities in aqueous extract of Argentine plants. Int. J. Pharmacogn. 1997, 35, 116-120. [CrossRef] 